RESEARCH ARTICLE

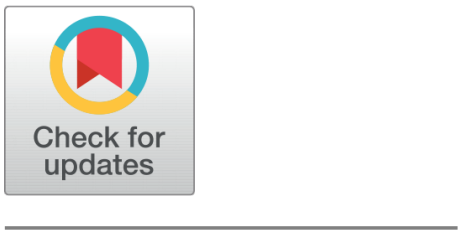

OPEN ACCESS

Received: 10.08 .2021

Accepted: 11.09 .2021

Published: 20.10 .2021

Citation: Thirupathi $P$, Venkatraman BR (2021) Corrosion inhibition and thermodynamic studies on carbon steel in well water by ethanolic extract of Alpinia officinarum leaves (Lesser galangal) $-\mathrm{Zn}^{2+}$. Indian Journal of Science and Technology 14(33): 2711-2730. https://doi.org/ 10.17485/IJST/v14i33.1489

* Corresponding author.

Tel: +919750435441

chemthiru@yahoo.in

Funding: None

Competing Interests: None

Copyright: () 2021 Thirupathi \& Venkatraman. This is an open access article distributed under the terms of the Creative Commons Attribution License, which permits unrestricted use, distribution, and reproduction in any medium, provided the original author and source are credited.

Published By Indian Society for Education and Environment (iSee)

ISSN

Print: 0974-6846

Electronic: 0974-5645

\section{Corrosion inhibition and thermodynamic studies on carbon steel in well water by ethanolic extract of Alpinia officinarum leaves (Lesser galangal)- $\mathrm{Zn}^{2+}$}

\author{
P Thirupathi ${ }^{1}{ }^{*}$, B R Venkatraman ${ }^{1}$ \\ 1 PG \& Research, Department of Chemistry, Periyar E.V.R. College (Autonomous), Affiliated to \\ Bharathidasan University, Tiruchirappalli, 620023, Tamilnadu, India. Tel.: +919750435441
}

\section{Abstract}

Objectives: To examine the thermodynamics and kinetics of Alpinia officinarum's (AO) inhibitory response on carbon steel (CS) corrosion in well water. Weight-loss (WL), potentiodynamic polarization (PDP), electrochemical impedance spectroscopy (EIS) methods and various pHlevels are utilized to calculate the inhibition efficiency (IE) and corrosion rate (CR). Methods: WL and PDP and EIS techniques were performed to assess the corrosion inhibition and adsorption capacity of an ethanolic extract of AO leaves on the CS in well water. SEM and AFM techniques were analyzed to explore the creation of a safe layer onto the CS surface. Findings: The maximum IE of $93 \%$ is attained from the WL study at 303K. For the $\mathrm{AO}-\mathrm{Zn}^{2+}$ system, when the temperature is increased from $303 \mathrm{~K}$ to $343 \mathrm{~K}, \mathrm{CR}$ is also increased and IE is decreased. Arrhenius plots show a straight line, indicating the effect of temperatures on the CR. PDP findings indicate that the $\mathrm{AO}-\mathrm{Zn}^{2+}$ system performs as a mixed-type inhibitor. The $\Delta \mathrm{G}_{a d s}$ values are less than $-20 \mathrm{KJ} / \mathrm{mol}$, signifying that physisorption on the CS surface has occurred. The positive values of $\Delta \mathrm{H}$ demonstrate $\mathrm{AO}$ leaves are adsorbing endothermically onto CS surface. The high adsorption of ethanolic extract of AO leaves on the CS surface in well water is reflected by positive activation energy values. Langmuir model is the best fit for the adsorption of ethanolic extract of AO leaves. Novelty: The nature of the adsorption process on the CS surface in well water was investigated by thermodynamic parameters $\left(\Delta \mathrm{G}_{a d s}\right.$, $\left.\mathrm{q}_{a d s}, \Delta \mathrm{S}_{a d s}, \Delta \mathrm{H}\right)$ and activation energy $\left(\mathrm{E}_{a}\right)$ using a combined inhibitor $\left(\mathrm{AO}-\mathrm{Zn}^{2+}\right)$ system. The regression coefficient $\left(R^{2}\right)$ values were calculated using the various adsorption isotherms to determine the pattern of inhibition on the CS surface. The F-test and synergism parameters were used to establish the synergistic inhibition (SI) impact existing between ethanolic extract of $\mathrm{AO}$ leaves and $\mathrm{Zn}^{2+}$.

Keywords: Green corrosion inhibitor; thermodynamics; kinetics; PDP; EIS; SEM; AFM; FTIR; adsorption models; synergism parameters 


\section{Inroduction}

Corrosion is a natural chemical process of transforming metal and alloy structures into chemically stable oxides, hydroxides and sulphides ${ }^{(1)}$. Carbon steel (CS) corrosion is a prevalent issue in the petroleum industry ${ }^{(2)}$. Steel Corrosion and its alloys have a well-studied industrial problem ${ }^{(3)}$. Natural inhibitors are earning a lot of attention in the corrosion domain due to their safety, cheap, good biocompatibility, environmentally suitability and recyclability ${ }^{(4)}$. Naturally occurring substances (Amino acids, alkaloids, polyphenols $)^{(5-7)}$ and plant extracts ${ }^{(8)}$ are examples of widely disseminated and low-value materials such as pollutants of agricultural production activities and its wastes. Inhibition positions by material choice, utilization of defensive coatings, and cycle conditions/climate change as perhaps the most well-known method utilized for corrosion control. Natural compounds that are emphatically polar functional sets are regularly utilized corrosion inhibitors, a significant number of which depend on nitrogen, $\mathrm{S}, \mathrm{P}$ and $\mathrm{O}^{(9,10)}$, considering adsorption on the CS surface, which has been seen to depend on the physicochemical properties of the functional groups and the thickness of electrons in the giver atom. In corrosion studies, the WL study is the best method to calculate the $\mathrm{CR}^{(3)}$. When the combined inhibitor is added to the blank system, the IE and CR is evaluated using different concentration of inhibitor onto metal surface ${ }^{(11)}$. PDP and EIS studies indicate that the mode of inhibition of plant extract for the corrosion resistance on the CS surface ${ }^{(3)}$. Metals exist in nature as chemical compounds, which demand the extractions of energy from their mineral form, as well as in equivalent amount of energy for chemical and electrochemical reactions during corrosion. As a result of the corrosion process, metals revert to their natural state ${ }^{(12)}$. The most prominent study in the recent times has been the hunt for environmentally safe, easily degradable, and abundantly present inhibitors. Natural elements such as fruits, leaves and flowers have been shown to effective corrosion inhibitors ${ }^{(13)}$. Plant extract has been reported as one of the most cost-effective, degradable, water soluble and environmentally friendly metal corrosion inhibitors. It is non-toxic, pure and readily available ${ }^{(14-19)}$. The Alpinia officinarum $-\mathrm{Zn}^{2+}$ system has been explored for its ability to control CS corrosion in well water, corrosion inhibition of ethanolic extract of AO leaves has been investigated, and it is inferred as a good prevent from corrosion. Synergistic and Antagonistic effect of plant extract is investigated ${ }^{(20)}$. The corrosion inhibition performance of CS is discussed by green inhibitor- $\mathrm{Zn}^{2+}$ system $^{(19-25)}$.

\section{Experimental Techniques:}

\subsection{Preparation of carbon steel (CS) specimens:}

CS specimens were cut into $3.5 \mathrm{~cm} \times 1.5 \mathrm{~cm} \times 0.2 \mathrm{~cm}$ for examinations. These CS were polished using $1 / 0$ to $6 / 0$ grade emery sheets. To remove contaminants, they were degreased through acetone, washed in double distilled (DD) water and dried and kept in a desiccator before weighing and dipping. All the weighing was done through digital balance (Shimadzu AY62) by a sensitivity of $0.1 \mathrm{mg}$ in $200 \mathrm{~g}$ range. The CS specimens were serially numbered for identification. For inserting the hook, a small smooth hole of $0.2 \mathrm{~mm}$ was drilled nearby the top edge centre of the specimen, the surface of CS specimens were carefully coated with epoxy resin (araldite) leaving $1 \mathrm{~cm}^{2}$ exposed surface area.

\subsection{Preparation of ethanolic extract of Alpinia officinarum leaves}

The AO plant leaves were cut into little bits and dried in an air oven at $70^{\circ} \mathrm{C}$ for $2 \mathrm{~h}$. They were finely pulverized into powder. The sample (10g) was dissolved in $200 \mathrm{ml}$ ethanol and then refluxed for $3 \mathrm{~h}$ in a $250 \mathrm{ml} \mathrm{RB}$ flask. The refluxed solution was then thoroughly filtered through Whatmann filter paper and filtrate was heated on a water bath to completely vaporize the moisture content, yielding the dry compound. The dried compound (1g) was dissolved in a $100 \mathrm{ml}$ standard measuring flask filled to the mark with DD water. Corrosion test solutions ranging from 100ppm to 500ppm were made from the stock solution using a specific quantity of ethanolic extract of plant leaves in well water and using it for the corrosion investigations. 


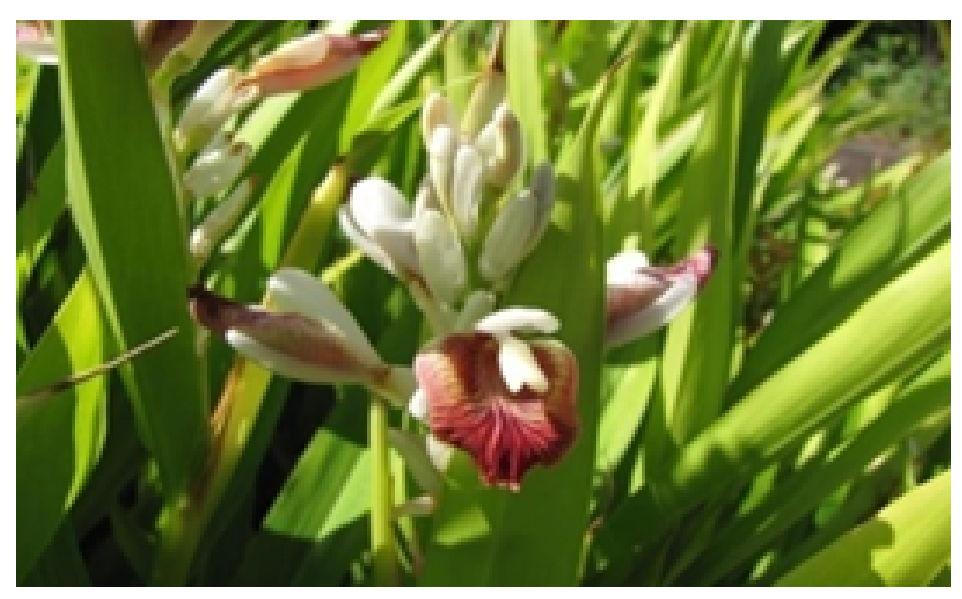

Fig 1. Alpinia officinarum leaves

It reduces postprandial blood glucose increases by inhibiting carbohydrate metabolism. The recovery of insulin-discharging ß-cells in the pancreas can be aided by eating bits of galangal.

\begin{tabular}{|c|c|c|}
\hline Sl.No. & Kingdom & Plantae \\
\hline 1 & Class & Liliopsida \\
\hline 2 & Order & Zingiberales \\
\hline 3 & Family & Zingiberaceae \\
\hline 4 & Common Name & Lesser galangal \\
\hline 5 & Tamil Name & Chitharathai \\
\hline 7 & Genus & Alpinia \\
\hline 8 & Species & Alpinia officinarum \\
\hline
\end{tabular}

\subsection{Mass spectrum (MS) study}

The structure of the bioactive component (Beta-caryophyllen) found in ethanolic extract of AO leaves is presented below and, Figure 2 represents the mass spectrum of the key active constituent found in the ethanolic extract of AO leaves.

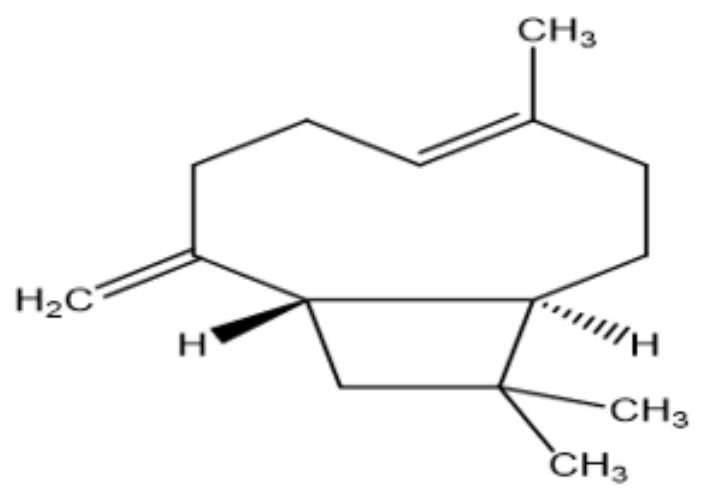

Beta-Caryophyllen 


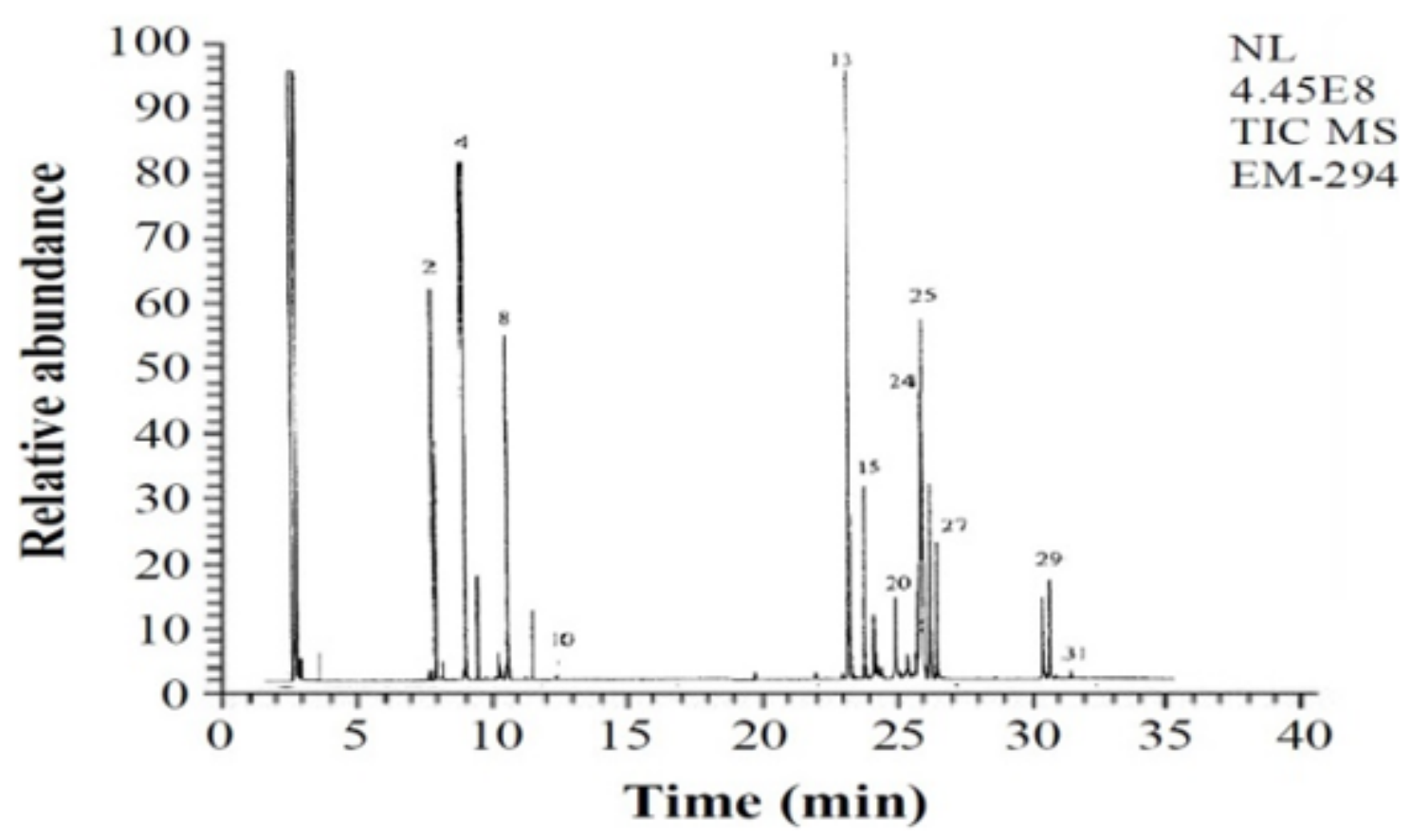

Fig 2. Structure of bioactive component and mass spectrum of major active constituents

\subsection{Weight-loss method (WL)}

WL study was operated to calculate the CR and percentage of IE ${ }^{(26)}$. CS specimens were polished to mirror finish by $1 / 0$ to 6/0 grade emery sheets, degreased through acetone, washed with DD water, dried with an air drier and kept in a desiccator for 15minutes. Then the CS specimens were weighed accurately using digital balance (Shimadzu AY62).

\subsection{Determination of IE and CR}

The corrosion inhibition of the ethanolic extract of AO leaves can be determined using weight-loss study. CS was immersed in well water with various concentrations of AO leaves at 303K. After one day of immersion, CS samples were collected, washed with tap water, dried and gauged to determine the $\mathrm{IE}^{(27,28)}$ and $\mathrm{CR}^{(28-30)}$ using the following equations:

$$
I E \%=\frac{W_{B}-W_{I}}{W_{B}} \times 100
$$

Where, $\mathrm{W}_{B}$ and $\mathrm{W}_{I}$ is the weight-loss for Blank and inhibitor system.

$$
C R(\text { mmpy })=\frac{87.6 \times W L(m g)}{D \times A \times T}
$$

Where, mmpy is millimetres per year, WL is weight-loss, D is Density $\left(7.85 \mathrm{~g} / \mathrm{cm}^{2}\right)$, A is surface area $\left(\mathrm{cm}^{2}\right)$ and Timmersion period (h).

\subsection{Calculation of surface coverage $(\theta)$}

Surface coverage values can be calculated using the WL study ${ }^{(31)}$. These values are used to identify the nature of the adsorption for combined inhibitor molecules $\left(\mathrm{AO}-\mathrm{Zn}^{2+}\right)$ and a suitable isotherm model to the adsorption process.

When the IE value is $100 \%$, the surface coverage value should be unity ${ }^{(28)}$.

$$
\theta=\frac{I E}{100}
$$




\subsection{Electrochemical techniques}

EIS and PDP methods were directed in three-cathode electrochemical cell gathering by utilizing the model:760D, CHI (electrochemical analyzer). A reference electrode operates as a saturated calomel electrode. The Counter electrode serves as a platinum $(\mathrm{Pt})$ sheet. CS specimen behaves as a working electrode. IE was calculated using the following formulas ${ }^{(32)}$.

$$
I E(\%)=\left(1-\frac{R_{c t(\text { Blank })}}{R_{c t(\text { Inhibitor })}}\right) \times 100
$$

Where, $\mathrm{R}_{c t}$ is charge transfer resistance of blank and $\mathrm{AO}-\mathrm{Zn}^{2+}$ system.

$$
I E(\%)=\left(1-\frac{I_{\text {corrosion }(\text { Inhibitor })}}{I_{\text {corrosion }(\text { Blank })}}\right) \times 100
$$

Where, ' $\mathrm{I}_{\text {corrosion }}$ ' is corrosion potential of the $\mathrm{AO}-\mathrm{Zn}^{2+}$ and blank system.

\subsection{Atomic force microscopy (AFM)}

AFM is one of the most powerful techniques for understanding the surface morphology ${ }^{(33,34)}$. It has become a highly reliable tool for roughness investigation of surfaces ${ }^{(35)}$. Two dimensional (2D) AFM images were obtained using the Veeco dinnova instrument with a scan rate of $0.6 \mathrm{~Hz} / \mathrm{Seconds}$. AFM image analyses were performed to obtain the root mean square roughness $\left(\mathrm{R}_{r m s}\right)$, average roughness $\left(\mathrm{R}_{a}\right)$ and maximum peak to valley height $(\mathrm{P}-\mathrm{V})$ values ${ }^{(36)}$.

\subsection{Scanning electron microscopy (SEM)}

SEM study was carried out in JEOL MODEL 6390-SEM. SEM images of pure CS specimen (uncorroded), CS submerged in well water without inhibitor for one day duration (corroded) and CS specimens submerged in well water with an optimum concentration of inhibitor for one day duration (protected) were taken. These SEM images were analyzed to compare the smoothness on the surface of CS and to conclude the adsorption film formation by the inhibitor on the CS specimens ${ }^{(37-39)}$.

\section{Results and discussion}

\subsection{Weight-loss method for AO-Zn ${ }^{2+}$ system}

Weight-loss study was carried out for CS specimens immersed in well water for one day in the absence and presence of different concentrations of $\mathrm{Zn}^{2+}$ ions $(10,20$ and $30 \mathrm{ppm})$ and ethanolic extract of AO leaves. The IE and CR are calculated and given in Table 2. IE and different concentrations of $\mathrm{AO}$ leaves $\left(100,200,300,400\right.$ and 500ppm) in absence and presence of $\mathrm{Zn}^{2+}$ is plotted (IE Vs ppm) and displayed in Figure 3.

\begin{tabular}{|c|c|c|c|c|c|c|c|c|}
\hline \multirow{3}{*}{$\mathrm{AO}(\mathrm{ppm})$} & IE \% & \multicolumn{7}{|c|}{ CR (mmpy) } \\
\hline & \multicolumn{8}{|c|}{$\mathrm{Zn}^{2+}(\mathrm{ppm})$} \\
\hline & 0 & 10 & 20 & 30 & 0 & 10 & 20 & 30 \\
\hline 0 & - & 19 & 21 & 29 & 0.1809 & 0.1465 & 0.1429 & 0.1284 \\
\hline 100 & 32 & 37 & 42 & 49 & 0.1230 & 0.1140 & 0.1049 & 0.0923 \\
\hline 200 & 40 & 51 & 48 & 56 & 0.1085 & 0.1013 & 0.0886 & 0.0796 \\
\hline 300 & 46 & 59 & 57 & 62 & 0.0977 & 0.0742 & 0.0777 & 0.0687 \\
\hline 400 & 57 & 68 & 71 & 81 & 0.0778 & 0.0579 & 0.0525 & 0.0344 \\
\hline 500 & 63 & 73 & 80 & 93 & 0.0669 & 0.0488 & 0.0362 & 0.0127 \\
\hline
\end{tabular}

Table 2. Data of IE andCR for AO $-\mathrm{Zn}^{2+}$ system (Period of immersion: 1 day)

An ethanolic extract of AO leaves (500ppm) alone offered 63\% IE and dropped the CR from 0.1809 to 0.0669, while 30ppm of $\mathrm{Zn}^{2+}$ alone offered 29\% IE and dropped the CR from 0.1809 to 0.1284 (Table 2). The IE of AO and $\mathrm{Zn}^{2+}$ alone do not have maximum. However, the combination of $\mathrm{AO}(500 \mathrm{ppm})$ and $\mathrm{Zn}^{2+}(30 \mathrm{ppm})$ has an IE of 93\% and CR of 0.0127 , making it the maximum IE for AO- $\mathrm{Zn}^{2+}$ system. Therefore, the IE is increased and CR is also reduced, when the concentration of combined inhibitor $\left(\mathrm{AO}-\mathrm{Zn}^{2+}\right)$ system is increased ${ }^{(30,40)}$. 
Anodic reaction ${ }^{(28,41)}: \mathrm{Fe} \rightarrow \mathrm{Fe}^{2+}+2 e^{-}$

Cathodic reaction $^{(41)}: \mathrm{O}_{2}+2 \mathrm{H}_{2} \mathrm{O}+4 e^{-} \rightarrow 4 \mathrm{OH}^{-}$

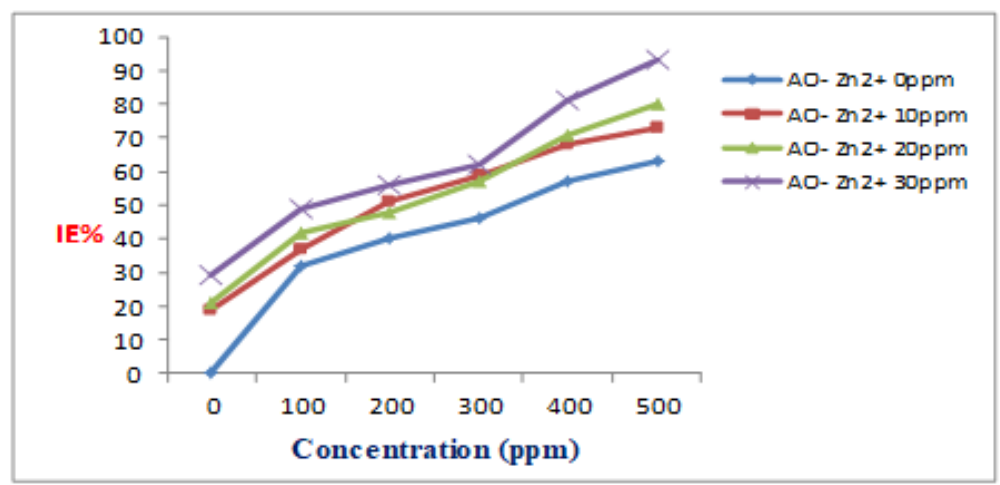

Fig 3. Concentration(ppm) Vs IE (\%) for $\mathrm{AO}-\mathrm{Zn}^{2+}$ System

\subsection{Effect of pH on AO - $\mathrm{Zn}^{2+}$ System}

The IE and CR are computed using different $\mathrm{pH}$ levels. At $\mathrm{pH} 8, \mathrm{AO}(500 \mathrm{ppm})$ and $\mathrm{Zn}^{2+}$ (30ppm) provide the highest IE of $93 \%$. Table 3 provides the data on the influence of $\mathrm{pH}$ on $\mathrm{AO}-\mathrm{Zn}^{2+}$ system. The maximum CR was found from an ethanolic extract of $\mathrm{AO}$ leaves at $\mathrm{pH} 3.0$; when the $\mathrm{pH}$ was lowered to 3 by adding dilute $\mathrm{HCl}$, the IE was reduced. This is because, at $\mathrm{pH}$ 8 , the protective film of the ethanolic extract of $\mathrm{AO}$ leaves is damaged by the robust attack of $\mathrm{H}^{+}$ions when the acid is added. The CR has been reduced from 0.0496 to 0.0127 for $\mathrm{AO}-\mathrm{Zn}^{2+}$ system. When $\mathrm{pH}$ of an ethanolic extract of AO leaves is raised to 12 by adding $\mathrm{NaOH}$, the CR increases. This could be related to may be the fact that at high $\mathrm{pH}$, the amount of $\mathrm{Zn}^{2+}$ accessible for transport towards the CS surface is reduced, as $\mathrm{Zn}^{2+}$ in a bulk solution precipitate as $\mathrm{Zn}(\mathrm{OH})_{2}{ }^{(42,43)}$. Graph for effect of $\mathrm{pH}$ on $\mathrm{CR}$ for $\mathrm{AO}-\mathrm{Zn}^{2+}$ system is given in Figure 4 .

Table 3. Dataof IE and CR for AO- $\mathrm{Zn}^{2+}$ system (Period of Immersion: one day)

\begin{tabular}{llll}
\hline \multirow{2}{*}{$\mathrm{pH}$} & \multicolumn{2}{l}{ CR (mmpy) } & IE (\%) \\
\cline { 2 - 3 } & Well water (Blank) & ${\mathrm{AO}-\mathrm{Zn}^{2+}(500-30 \mathrm{ppm}) \text { system }}^{2}$ & 76 \\
\hline 3 & 0.2067 & 0.0496 & 93 \\
12 & 0.1809 & 0.0127 & 86 \\
\hline
\end{tabular}

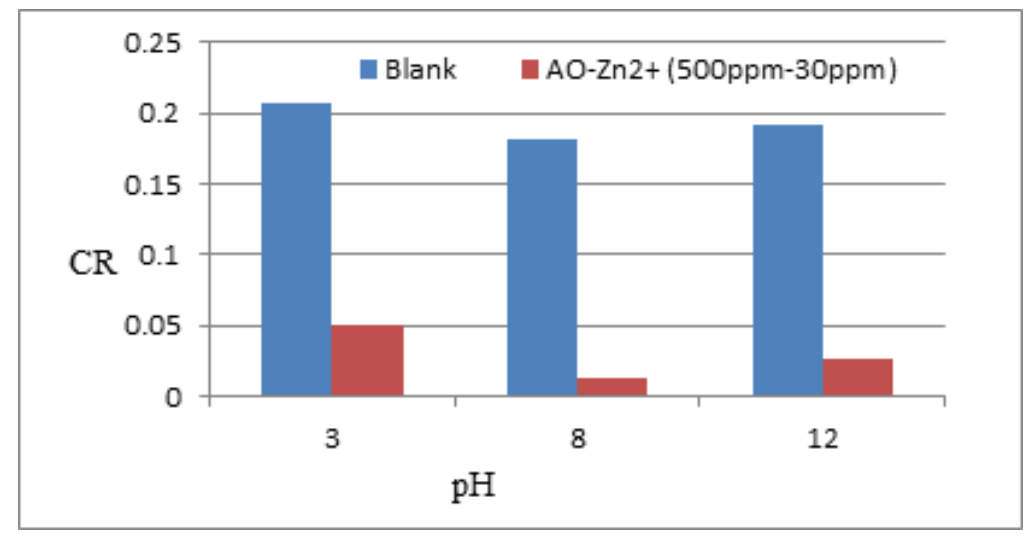

Fig 4. Effect of $\mathrm{pH}$ on $\mathrm{CR}$ for $\mathrm{AO}-\mathrm{Zn}^{2+}$ system 


\subsection{Effect of Immersion Period on AO-Zn ${ }^{2+}$ System:}

The weight-loss investigation for the CS in well water containing various concentrations of AO leaves with additive of $\mathrm{Zn}^{2+}$ ions was used to investigate the effect of immersion period at 1, 3, 5, and 7 days. Table 4 summarizes these findings. Figure 5 shows the IE and CR of combined inhibitor (500ppm of ethanolic extract of AO leaves: $30 \mathrm{ppm}$ of $\mathrm{Zn}^{2+}$ ) system as well as the effect of immersion period (1, 3, 5 and 7 days). The maximum IE of $93 \%$ is recorded from a $500 \mathrm{ppm}$ of $\mathrm{AO}$ and $30 \mathrm{ppm}^{\mathrm{p}} \mathrm{Zn} \mathrm{n}^{2+}$ system in one day immersion period at $303 \mathrm{~K}$. The percentage of IE is reduced for AO leaves extract, when contact period is increased from 1 to 7 (days) ${ }^{(44)}$. The effect of immersion period on an ethanolic extract of AO leaves proved that protective layer formed on the CS surface deteriorates and dissolves in solution by the corrosion media and accelerates the corrosion process ${ }^{(42,45-48)}$.

Table 4. Effect of Immersion period on $\mathrm{AO}-\mathrm{Zn}^{2+}$ System

\begin{tabular}{llll}
\hline \multirow{2}{*}{$\begin{array}{l}\text { Immersion period } \\
\text { (days) }\end{array}$} & \multicolumn{2}{l}{$\mathrm{CR}(\mathrm{mmpy})$} & $\mathrm{IE} \%$ \\
\cline { 2 - 3 } & Well water & ${\mathrm{AO}-\mathrm{Zn}^{2+}(500 \mathrm{ppm}-30 \mathrm{ppm})}$ & 93 \\
1 & 0.1809 & 0.0127 & 89 \\
3 & 0.2013 & 0.0221 & 82 \\
7 & 0.2124 & 0.0382 & 75 \\
\hline
\end{tabular}

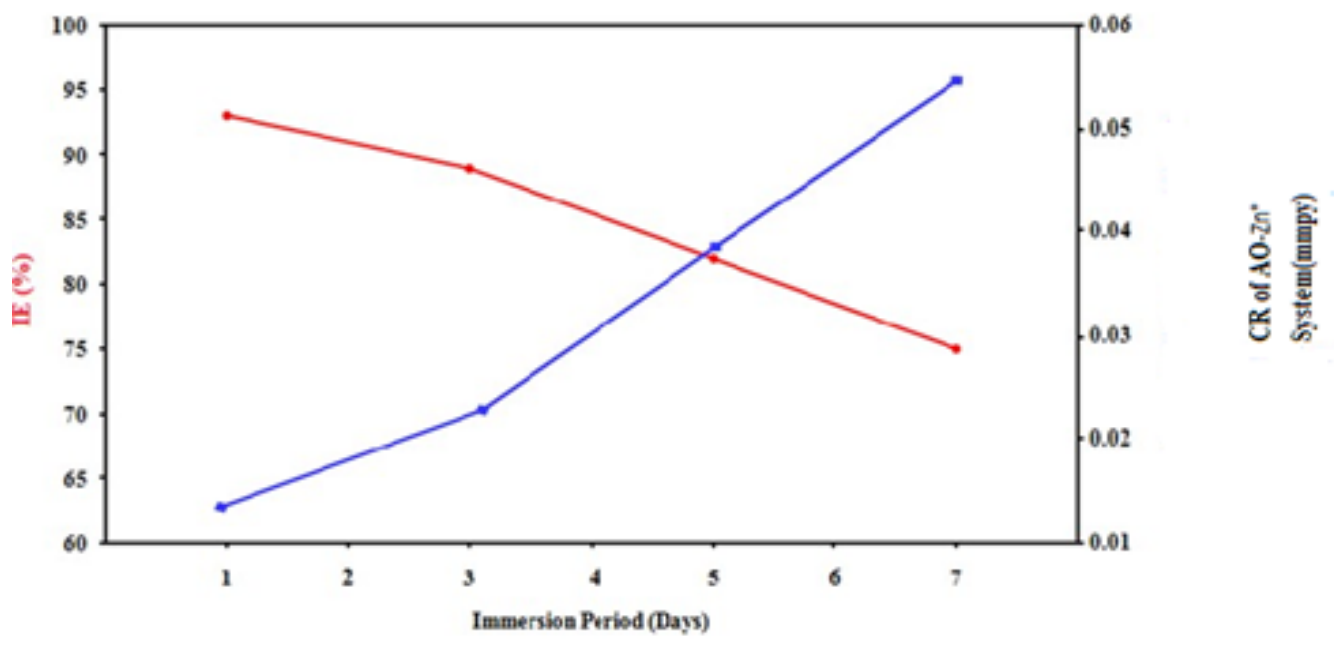

Fig 5. Effect of immersion period on the IE and CR for AO- $\mathrm{Zn}^{2+}$ system

\subsection{Effect of temperature on CR and IE}

The CR and IE were computed for the CS immersed in well water containing the ethanolic extract of AO leaves at various temperatures $(313 \mathrm{~K}, 323 \mathrm{~K}, 333 \mathrm{~K}$ and $343 \mathrm{~K})$ using weight-loss study. Table 5 summarizes the observed CR and IE for AO-Zn ${ }^{2+}$ system. When the temperature is increased from $303 \mathrm{~K}$ to $343 \mathrm{~K}$, the CR is increased and also IE is decreased. Due to enhance desorption process on the CS surface at higher temperature ${ }^{(12)}$ and solubility of the protective film formed rapidly on the CS surface ${ }^{(49)}$. This finding suggested that the components of the ethanolic extract of AO leaves are physisorbed on the CS surface $^{(49-52)}$. Figure 6 depicts the effect of temperature on IE using various concentration of AO extract. 
Table 5. Effect of temperature on CR and IE

\begin{tabular}{|c|c|c|c|c|c|c|c|c|c|c|}
\hline \multirow{3}{*}{$\begin{array}{l}\mathrm{AO} \\
\text { System } \\
(\mathrm{ppm})\end{array}$} & \multicolumn{10}{|c|}{ Temperature (K) } \\
\hline & \multicolumn{2}{|l|}{303} & \multicolumn{2}{|l|}{313} & \multicolumn{2}{|l|}{323} & \multicolumn{2}{|l|}{333} & \multicolumn{2}{|l|}{343} \\
\hline & IE (\%) & $\begin{array}{l}\text { CR } \\
\text { (mmpy) }\end{array}$ & IE (\%) & $\begin{array}{l}\text { CR } \\
\text { (mmpy) }\end{array}$ & IE (\%) & CR (mmpy) & IE (\%) & $\begin{array}{l}\text { CR } \\
\text { (mmpy) }\end{array}$ & IE (\%) & CR (mmpy) \\
\hline Blank & - & 0.1809 & - & 0.2248 & - & 0.2437 & - & 0.2728 & - & 0.3102 \\
\hline 100 & 49 & 0.0923 & 45 & 0.1822 & 41 & 0.2002 & 40 & 0.2066 & 30 & 0.2711 \\
\hline 200 & 56 & 0.0796 & 52 & 0.1669 & 46 & 01939 & 40 & 0.2066 & 34 & 0.2328 \\
\hline 300 & 62 & 0.0687 & 58 & 0.1599 & 52 & 0.1590 & 46 & 0.1999 & 55 & 0.1821 \\
\hline 400 & 81 & 0.0344 & 76 & 0.0849 & 70 & 0.1396 & 63 & 0.1569 & 61 & 0.1563 \\
\hline 500 & 93 & 0.0127 & 89 & 0.0590 & 84 & 0.0896 & 77 & 0.1162 & 70 & 0.1231 \\
\hline
\end{tabular}

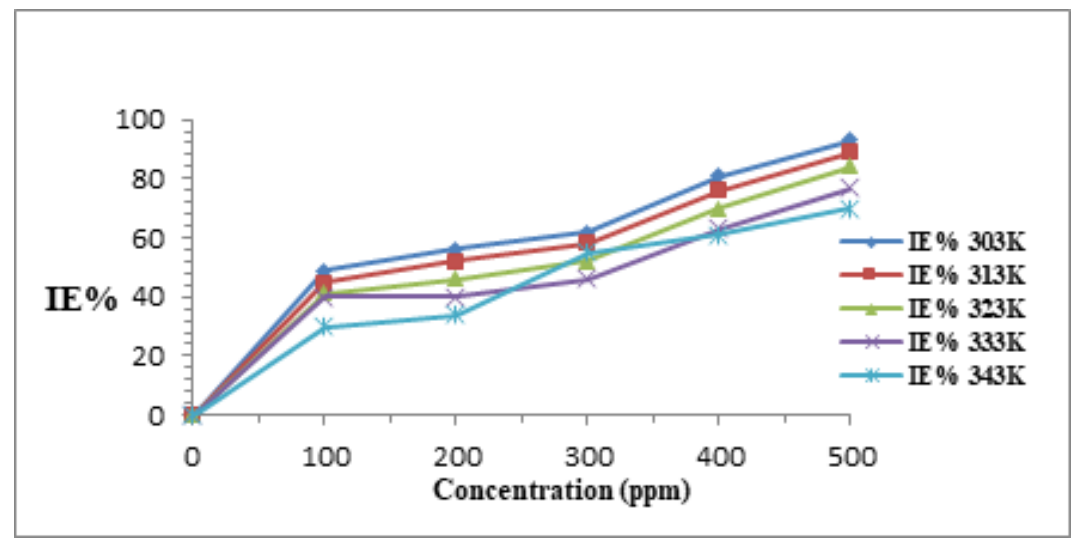

Fig 6. Effect of temperature on the IE for $\mathrm{AO}-\mathrm{Zn}^{2+}$ system

\subsection{Kinetic Studies on Temperatures}

The effect of temperature on the CR is indicated by Arrhenius plots, which show a straight line for blank and an optimum concentration of ethanolic extract of AO leaves on the CS in well water. The Arrhenius plots are drawn between CR and 1/T for $303 \mathrm{~K}, 313 \mathrm{~K}, 323 \mathrm{~K}$, and 333K (Figure 7).

Arrhenius equation $^{(53)}: \ln C R=\ln A-\frac{E_{a}}{R T}$

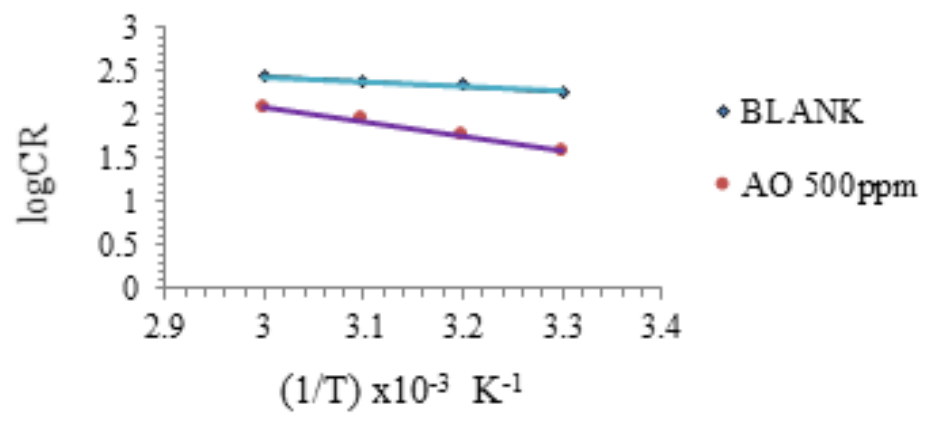

Fig 7. Arrhenius plots for blank and 500ppm of AO leaves 


\subsection{Kinetic studies on corrosion process}

Activation energy $\left(\mathrm{E}_{a}\right)$ and enthalpy change data were computed to identify the adsorption process and type of reaction on the $\mathrm{CS}$ surface using ethanolic extract of AO leaves- $\mathrm{Zn}^{2+}$. When the concentration of ethanolic extract of AO leaves is raised, $\mathrm{E}_{a}$ and $\Delta \mathrm{H}$ values are increased. $\mathrm{E}_{a}$ and $\Delta \mathrm{H}$ values are positive in sign. The positive values of $\mathrm{E}_{a}$ reveal that a highly adsorption on the CS surface ${ }^{(54)}$. The values of $\Delta \mathrm{H}$ indicate that adsorption of AO extract is endothermically on the CS surface ${ }^{(31,53,55-57)}$. The results are given in Table 6 .

The activation energy ${ }^{(27,30)}$ and enthalpy change ${ }^{(55)}$ values are calculated using the following equations.

$$
\begin{gathered}
E_{a}=R \operatorname{Rn}\left(\frac{C_{R T 1}}{C_{R T 2}}\right)\left[\frac{T_{1} T_{2}}{T_{2}-T_{1}}\right] \\
\triangle H=E_{a}-R T
\end{gathered}
$$

Table 6. Kinetic parameters

\begin{tabular}{lll}
\hline AO system $(\mathrm{ppm})$ & $\mathrm{Ea}\left(\mathrm{KJmol}^{-1}\right)$ & $\Delta \mathrm{H}\left(\mathrm{KJ} / \mathrm{mol}^{-1}\right)$ \\
\hline Blank & 17.1 & 14.6 \\
100 & 53.6 & 51.0 \\
200 & 58.4 & 55.8 \\
300 & 66.6 & 64.0 \\
400 & 71.3 & 68.7 \\
500 & 121.1 & 118.6 \\
\hline
\end{tabular}

\subsection{Thermodynamic studies on adsorption process}

Thermodynamic parameters are computed to detemine the type of adsorption on the surface of CS. Adsorption of ethanolic extract of AO leaves has a spontaneous process ${ }^{(40)}$ onto CS surface with physisorption ${ }^{(57)}$, as evidenced by the free energy of adsorption $\left(\Delta \mathrm{G}_{a d s}\right)$ and heat of adsorption $\left(\mathrm{q}_{a d s}\right)$ negative values ${ }^{(27,53)} . \Delta \mathrm{G}_{a d s}$ have negative values of less than $-20 \mathrm{KJmol}{ }^{-1}$, implying that the nature of adsorption is physisorption ${ }^{(30,53,56-59)}$ for the investigative inhibitor system. When compared to the other three temperatures, $\Delta \mathrm{G}_{a d s}$ has the highest negative value of $-18.4 \mathrm{KJmol}^{-1}$ at $303 \mathrm{~K}$ and the lowest negative value of $-16.4 \mathrm{KJmol}^{-1}$ at $333 \mathrm{~K}$. The negative values of entropy of adsorption $\left(\Delta \mathrm{S}_{a d s}\right)$ show that an ethanolic extract of AO leaves form a protective layer on the CS surface ${ }^{(53,54,56-58,60)}$. Result of thermodynamic parameters are given in Table 7 . The $\Delta \mathrm{G}_{a d s}{ }^{(53,61)}$, $\mathrm{q}_{a d s}{ }^{(27)}$ and $\Delta \mathrm{S}_{a d s}{ }^{(4,28,58)}$ values are calculated using the following equations.

$$
\triangle G_{a d s}=-R T \ln \left(55.5 K_{a d s}\right)
$$

$$
\begin{gathered}
q_{a d s}=2.303 R\left[\left(\frac{\theta_{T 2}}{1-\theta_{T 2}}\right)-\log \left(\frac{\theta_{T 1}}{1-\theta_{T 1}}\right)\left(\frac{T_{1} T_{2}}{T_{2}-T_{1}}\right)\right] \\
\triangle S_{a d s}=\frac{q_{a d s}-\triangle G_{a d s}}{T}
\end{gathered}
$$

Table 7. Thermodynamic parameters

\begin{tabular}{lllll}
\hline & Temperature $(\mathrm{K})$ & $\Delta \mathrm{G}_{a d s}\left(\mathrm{KJmol}^{-1}\right)$ & $\mathrm{q}_{a d s}\left(\mathrm{KJmol}^{-1}\right)$ & $\Delta \mathrm{S}_{a d s}\left(\mathrm{KJmol}^{-1}\right)$ \\
\cline { 2 - 5 } AO system & 303 & -18.4 & -39.1 & -0.190 \\
& 313 & -17.7 & -36.3 & -0.173 \\
& 323 & -17.1 & 40.2 & -0.176 \\
& 333 & -16.4 & -34.3 & -0.152 \\
\hline
\end{tabular}




\subsection{Adsorption isotherms}

Adsorption models are analyzed to identify the mode of corrosion inhibition, the nature of interaction between the adsorbed inhibitor and CS surface ${ }^{(62,63)}$. In present work, four adsorption isotherm models are studied for regression co-efficient $\left(\mathrm{R}^{2}\right)$ values obtained. From $\mathrm{R}^{2}$ values of four adsorption isotherm (Langmuir, Flory-Huggins, EL-Awady and Temkin) are almost equal to one ${ }^{(59,62-64)}$. $\mathrm{R}^{2}$ value of Langmuir isotherm model is much higher than other three adsorption model (Table 8 ). Therefore, the adsorption behavior of the inhibitor has followed a Langmuir model. All the isotherms are represented by the common form ${ }^{(31,65)}$.

$$
f(\theta, x) \exp (-2 a \theta)=K C
$$

Langmuir ${ }^{(29,31,50,53,58)}$, Flory-Huggins ${ }^{(30,62,63)}$, EL-Awady ${ }^{(30,63,66)}$ and Temkin ${ }^{(30,61,63)}$ isotherms are expressed by following equations.

Langmuir isotherm model:

$$
\frac{C_{\text {inhibitor }}}{\theta}=\frac{1}{K_{a d s}}+C_{\text {inhibitor }}
$$

EL-Awady isotherm model:

$$
\log \left(\frac{\theta}{1-\theta}\right)=\log (K+y c)
$$

Flory-Huggins isotherm model:

$$
\log \left(\frac{\theta}{C}\right)=\log K+x \log (1-\theta)
$$

Temkin isotherm model:

$$
\theta=-\frac{2.303}{2 a}\left(\log K_{a d s}+\log c\right)
$$

\begin{tabular}{|c|c|c|c|c|c|}
\hline & \multicolumn{5}{|c|}{ Temperature (K) } \\
\hline \multirow{3}{*}{$\mathrm{AO}-\mathrm{Zn}^{2+}$ system } & 303 & 313 & 323 & 333 & 343 \\
\hline & $\mathrm{K}_{a d s}$ & & & & \\
\hline & 26.6 & 16.2 & 10.5 & 6.7 & 4.7 \\
\hline
\end{tabular}

Table 8. Data for Adsorption isotherm parameters

\begin{tabular}{llll}
\hline \multicolumn{4}{c}{$\mathrm{AO}-\mathrm{Zn}^{2+}$ system } \\
\hline Adsorption isotherms & $\mathrm{R}^{2}$ & Slope & Intercept \\
\hline Langmuir & 0.997 & 139.5 & 69 \\
Flory-Huggins & 0.838 & -0.1016 & -2.292 \\
EL-Awady & 0.903 & 0.2807 & -0.431 \\
Temkin & 0.957 & 0.113 & 0.343 \\
\hline
\end{tabular}

Table 9. Data for Equilibrium constant $\left(\mathrm{K}_{a d s}\right)$

The equilibrium constant $\left(\mathrm{K}_{a d s}\right)$ values are increased, when the temperature is increased. From this result, $\mathrm{K}_{a d s}$ suggests that the safe layer formed is easily removing from the CS surface through solvent molecules ${ }^{(63)}$, due to desorption process in higher temperature. Therefore, $\mathrm{K}_{a d s}$ result is support to physisorption on the CS surface ${ }^{(67)}$. 


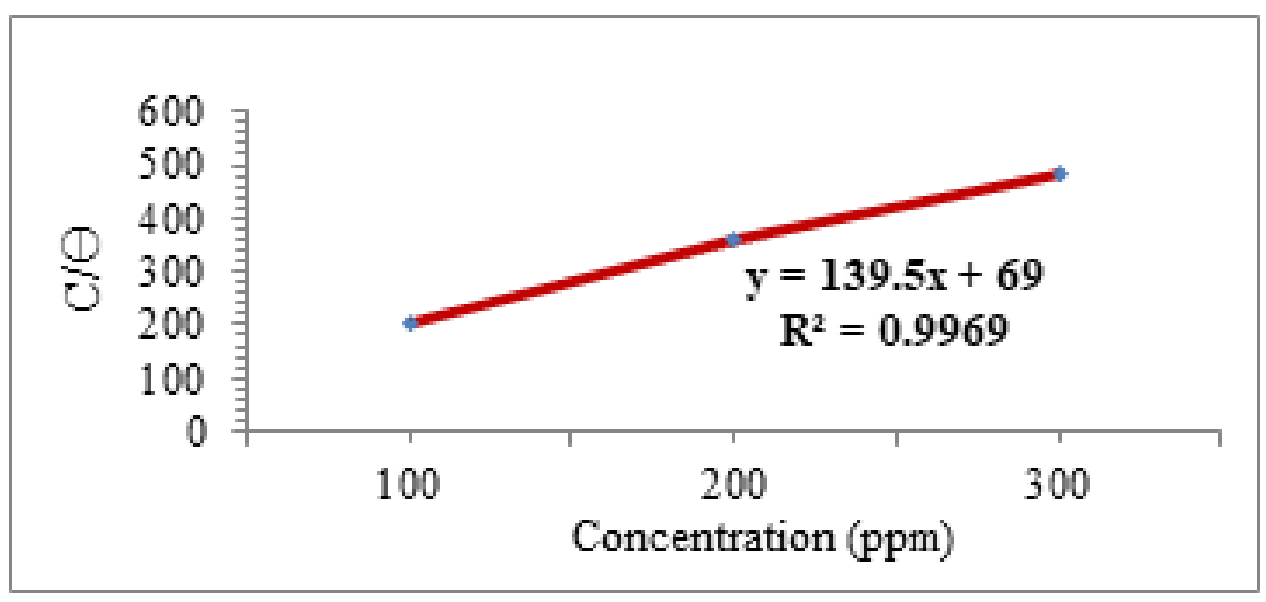

Fig 8. Langmuir adsorption isotherm at $303 \mathrm{~K}$

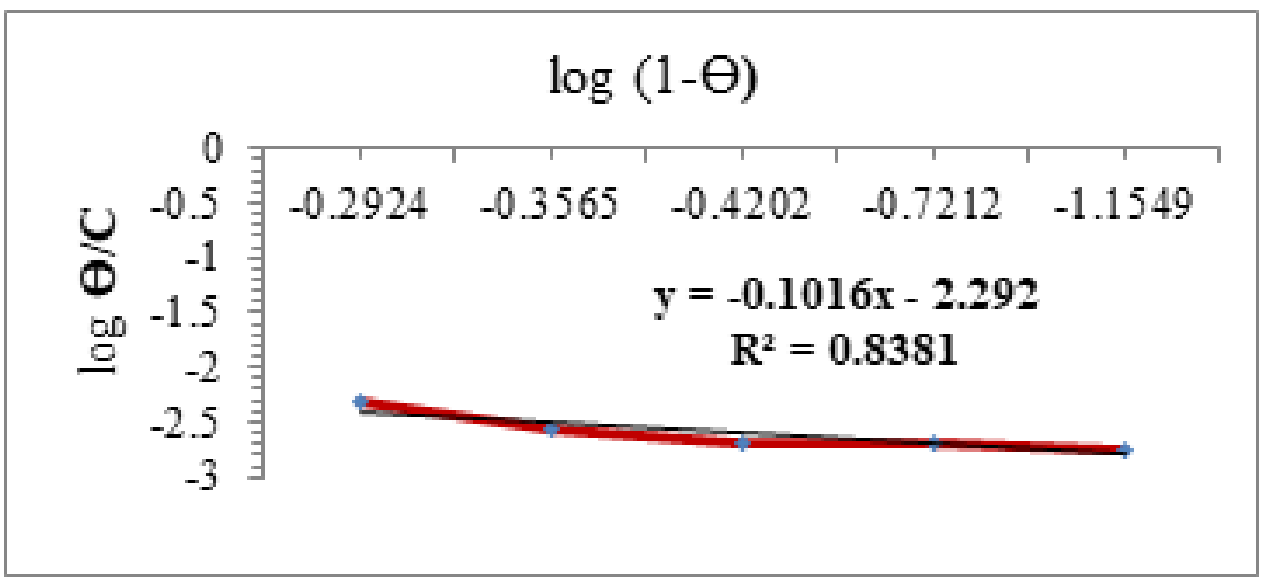

Fig 9. Flory-Huggins adsorption isotherm at 303K

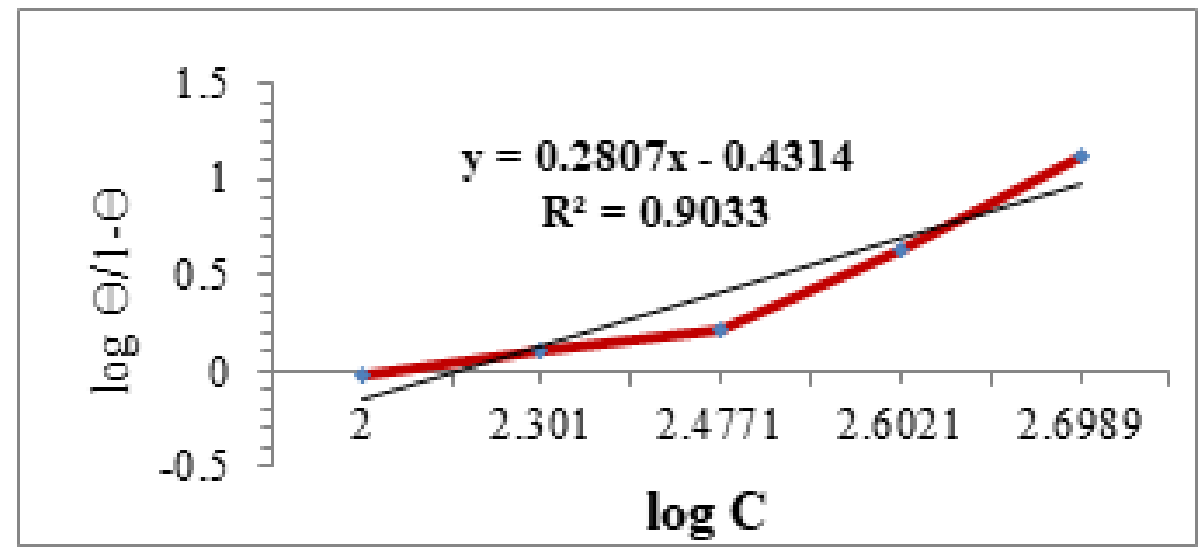

Fig 10. El-Awady adsorption isotherm at $303 \mathrm{~K}$ 


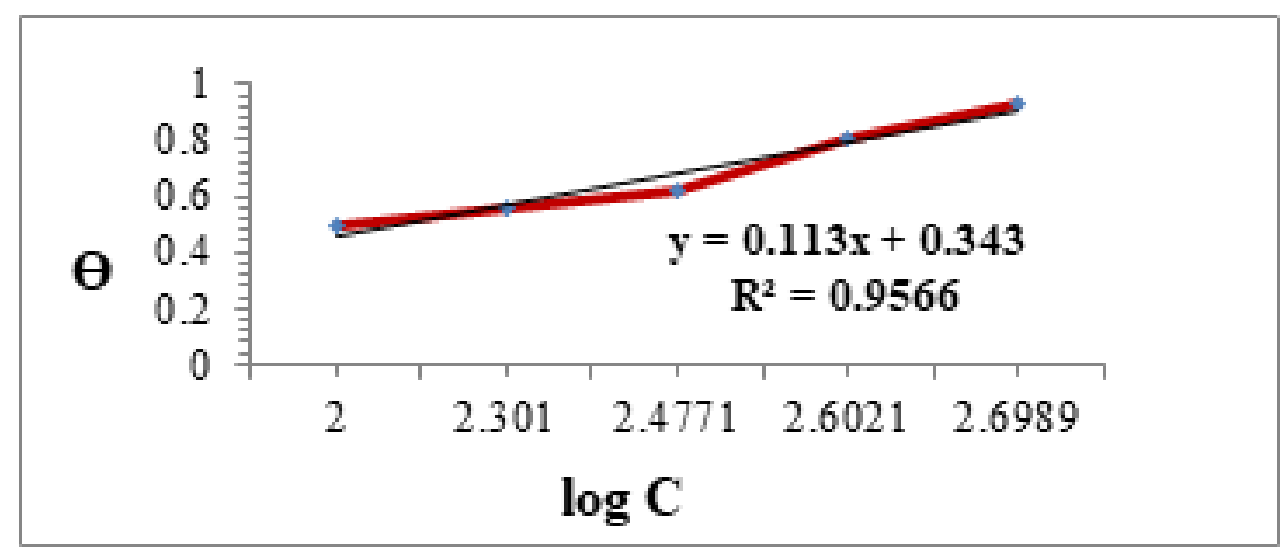

Fig 11. Temkin adsorption isotherm at $303 \mathrm{~K}$

\subsection{Synergism parameter (SI) :}

The synergism parameters are utilized to determine the synergistic effect of $\mathrm{AO}-\mathrm{Zn}^{2+}$ system ${ }^{(68)}$. Synergism parameter $\left(\mathrm{S}_{I}\right)$ is a measure of synergistic inhibition of corrosion $\left(\mathrm{S}_{I}\right)^{(69)}$. The synergism parameter $\left(\mathrm{S}_{I}\right)$ is computed by using the formula ${ }^{(67)}$ :

$$
S_{I}=\frac{1-\theta_{1+2}}{1-\theta^{\prime}{ }_{1+2}}
$$

Where $\theta_{1+2}=\left(\theta_{1}+\theta_{2}\right)-\left(\theta_{1} \times \theta_{2}\right) ;{ }^{\prime \prime} \theta_{1}$ ' and ' $\theta_{2}$ ' are surface coverage for $\mathrm{AO}-\mathrm{Zn}^{2+} ; \theta_{1+2}^{\prime}$ is cumulative surface coverage to $\mathrm{AO}-\mathrm{Zn}^{2+}$. The data for Synergism Parameters are given in Table 10 .

Table 10. Synergism Parameter for $\mathrm{AO}-\mathrm{Zn}^{2+}(500: 30 \mathrm{ppm})$ System

\begin{tabular}{lllllll}
\hline $\mathrm{AO}(\mathrm{ppm})$ & $\mathrm{Zn}^{2+}(\mathrm{ppm})$ & $\theta_{1}$ & $\theta_{2}$ & $\theta_{1+2}^{\prime}$ & $\mathrm{S}_{I}$ & IE \% \\
\hline 100 & 30 & 0.32 & 0.29 & 0.49 & 0.9467 & 49 \\
200 & 30 & 0.40 & 0.29 & 0.56 & 0.9682 & 56 \\
300 & 30 & 0.46 & 0.29 & 0.62 & 1.0090 & 62 \\
400 & 30 & 0.57 & 0.29 & 0.81 & 1.6069 & 81 \\
500 & 30 & 0.63 & 0.29 & 0.93 & 3.7529 & 93 \\
\hline
\end{tabular}

\subsection{F-study}

F-test was analyzed to examine the effect of $\mathrm{Zn}^{2+}$ on the IE of ethanolic extract of $\mathrm{AO}$ leaves as statistically significant or not onto CS surface ${ }^{(70,71)}$. Data of F study are shown in Table 11.

Table 11. The F-value distributed between the IE of AO- $\mathrm{Zn}^{2+}$ System

\begin{tabular}{|c|c|c|c|c|c|c|}
\hline $\mathrm{Zn}^{2+}(\mathrm{ppm})$ & $\begin{array}{l}\text { Level of Significance of } \\
\text { F }\end{array}$ & source of variance & sum of squares & degree of freedom & mean square & $\mathrm{F}$ \\
\hline \multirow{2}{*}{10} & \multirow{2}{*}{$\mathrm{P}>0.05$} & Between & 250 & 1 & 250 & \multirow{2}{*}{1.38} \\
\hline & & Within & 1444 & 8 & 180.55 & \\
\hline \multirow{2}{*}{20} & \multirow{2}{*}{$\mathrm{P}>0.05$} & Between & 360 & 1 & 360 & \multirow{2}{*}{1.77} \\
\hline & & Within & 1626.4 & 8 & 203.3 & \\
\hline \multirow{2}{*}{30} & \multirow{2}{*}{$\mathrm{P}>0.05$} & Between & 1060.9 & 1 & 1060.9 & \multirow{2}{*}{6.78} \\
\hline & & Within & 1964 & 8 & 156.5 & \\
\hline
\end{tabular}

The obtained F- values for $10 \mathrm{ppm}$ and $20 \mathrm{ppm}$ of $\mathrm{Zn}^{2+}$ are 1.38 and 1.77 for $\mathrm{AO}$ system. These F-values are smaller amount than the critical F-value 5.32. Hence, they are not statistically significant ${ }^{(47)}$. The calculated F-value for $30 \mathrm{ppm}$ of $\mathrm{Zn}^{2+}$ is 6.78 for the concentration of AO system. Because this value is higher than the critical F-value 5.32 , this value is statistically significant ${ }^{(47)}$. 


\subsection{Potentiodynamic polarization study}

PDP investigation yielded the data of Corrosion current ${ }^{(72)}$, corrosion potential ${ }^{(73)}$, anodic and cathodic slope values ${ }^{(74)}$ and linear polarization resistance ${ }^{(75)}$ obtained from Tafel curves. When the CS is submerged in blank system, corrosion potential is $580 \mathrm{mV}$. The AO- $\mathrm{Zn}^{2+}(500 \mathrm{ppm}-30 \mathrm{ppm})$ system shifted into $-620 \mathrm{mV}$ from $-580 \mathrm{mV}$ in a binary system. It has been reported ${ }^{(76)}$ that if the corrosion potential are greater than $85 \mathrm{mV}$ in well water, the type of inhibition mechanism is designated as either oxidation or reduction reaction. In this investigation, highest distortion shows through $\mathrm{AO}$ is $<41 \mathrm{mV}$, from which it could be attributed to the mixed mode of inhibition. Similar observations are observed and reported the inhibitive nature of AO extract to be mixed-type inhibitor ${ }^{(75)}$. LPR and $\mathrm{I}_{\text {corr }}$ value for well water is $963 \Omega \mathrm{cm}^{2}$ and $5.5431 \mu \mathrm{A} / \mathrm{cm}^{2}$ for $\mathrm{AO}-\mathrm{Zn}{ }^{2+}(500 \mathrm{ppm}$ $30 \mathrm{ppm}$ ) systems, the LPR is raised from 963 to $3249 \Omega \mathrm{cm}^{2}$, as well as $\mathrm{I}_{\text {corr }}$ is decreased to 0.9479 from $5.543 \mu \mathrm{A} / \mathrm{cm}^{2}$ for AO and $\mathrm{Zn}^{2+}$ system, Therefore, from the above result, the LPR values are increased but $\mathrm{I}_{\text {corr }}$ values are decreased ${ }^{(77)}$, when added the concentration of inhibitor to blank (well water) system. These results confirm the thin layer is developed on the CS surface ${ }^{(78)}$.

Table 12. Polarization Parameters for AO- $\mathrm{Zn}^{2+}$ System

\begin{tabular}{|c|c|c|c|c|c|}
\hline System & $\begin{array}{lll}\mathbf{E}_{\text {corr }} & (\mathrm{mV}) & \text { vs } \\
\text { SCE } & & \\
\end{array}$ & $\mathrm{b}_{\mathbf{a}}(\mathrm{mV} /$ decade $)$ & $\mathrm{b}_{\mathrm{c}}(\mathrm{mV} /$ decade $)$ & $\operatorname{LPR}\left(\Omega \mathrm{cm}^{2}\right)$ & $\mathbf{I}_{\text {corr }}\left(\mu \mathrm{A} / \mathrm{cm}^{2}\right)$ \\
\hline Well water (Blank) & -580 & 116.23 & 110.88 & 963 & 5.5431 \\
\hline $\mathrm{AO}-\mathrm{Zn}^{2+}(500: 30 \mathrm{ppm})$ & -620 & 111.36 & 116.69 & 3249 & 0.9479 \\
\hline
\end{tabular}

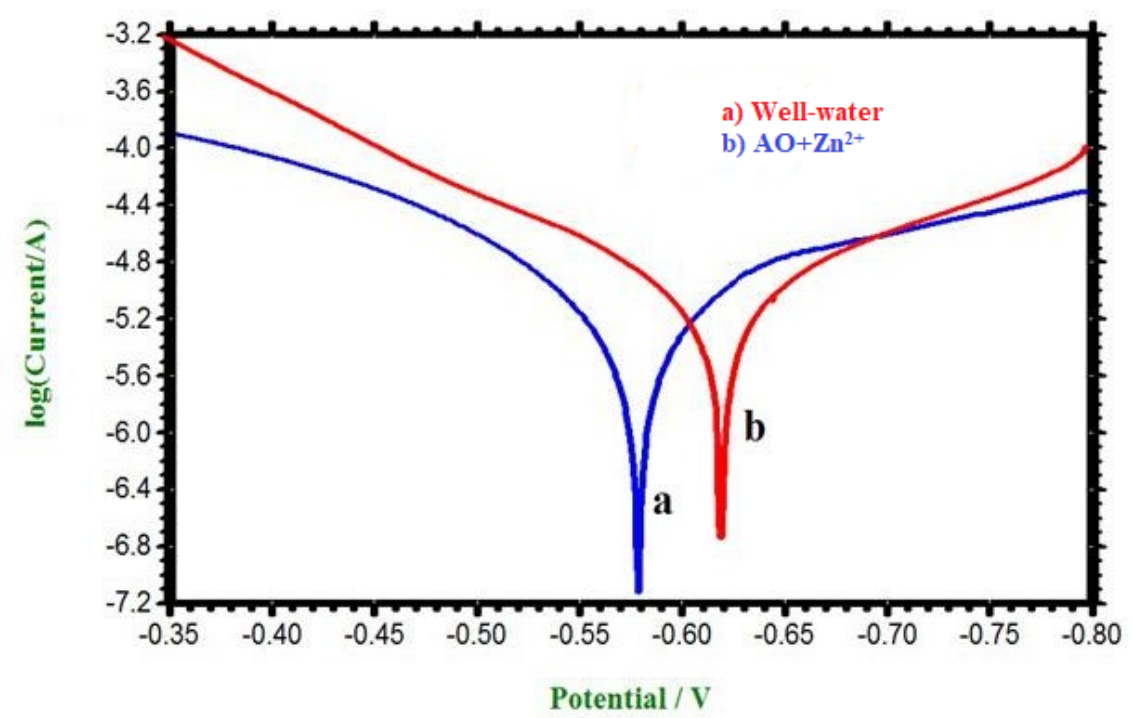

Fig 12. Tafel Curves for well-water (a) and AO- $\mathrm{Zn}^{2+}$ System (b)

\subsection{AC Impedance Spectra}

The EIS investigation was utilized to determine the safe film formed on the CS surface. During a thick layer formation on the CS surface using $\mathrm{AO}-\mathrm{Zn}^{2+}$ system, this incorporated with increases $\mathrm{R}_{c t}$ and reduces $\mathrm{C}_{d l}$ value ${ }^{\text {(79) }}$. The semicircle in this study implies that $\mathrm{R}_{c t}$ may be involved in the inhibition of corrosion process ${ }^{(80)}$. A semicircle is formed over a CS sheet by using $\mathrm{AC}$ impedance analysis to account for roughness and the interfacial phenomenon, a semicircle found to be deviated instead of ideal semicircle ${ }^{(81)}$. Table 13 shows the Nyquist plots' results. The CS immersed in well water has a $\mathrm{R}_{c t}$ of $391 \Omega \mathrm{cm}^{2}$ and a $\mathrm{C}_{d l}$ of $1.3137 \mu \mathrm{F} / \mathrm{cm}^{2}$. For the $\mathrm{AO}-\mathrm{Zn}^{2+}$ system, $\mathrm{R}_{c t}$ value has been increased from 391 to $2610 \Omega \mathrm{cm}^{2}$, while $\mathrm{C}_{d l}$ value has been dropped from 1.3137 to $0.02975 \mu \mathrm{F} / \mathrm{cm}^{2}$. When the inhibitor was added to the blank system, $\mathrm{R}_{c t}$ value increased while the $\mathrm{C}_{d l}$ value decreased. The thickness of a safe layer formation by adsorption of the inhibitor molecule is enhanced along $\mathrm{CS} /$ solution connection $^{(82,83)}$. The investigative inhibitor system acts as a good prevention activity on the CS surface in well water. The EIS spectra are given in Figure 13. 
Table 13. EIS Parameters for AO- $\mathrm{Zn}^{2+}$ System

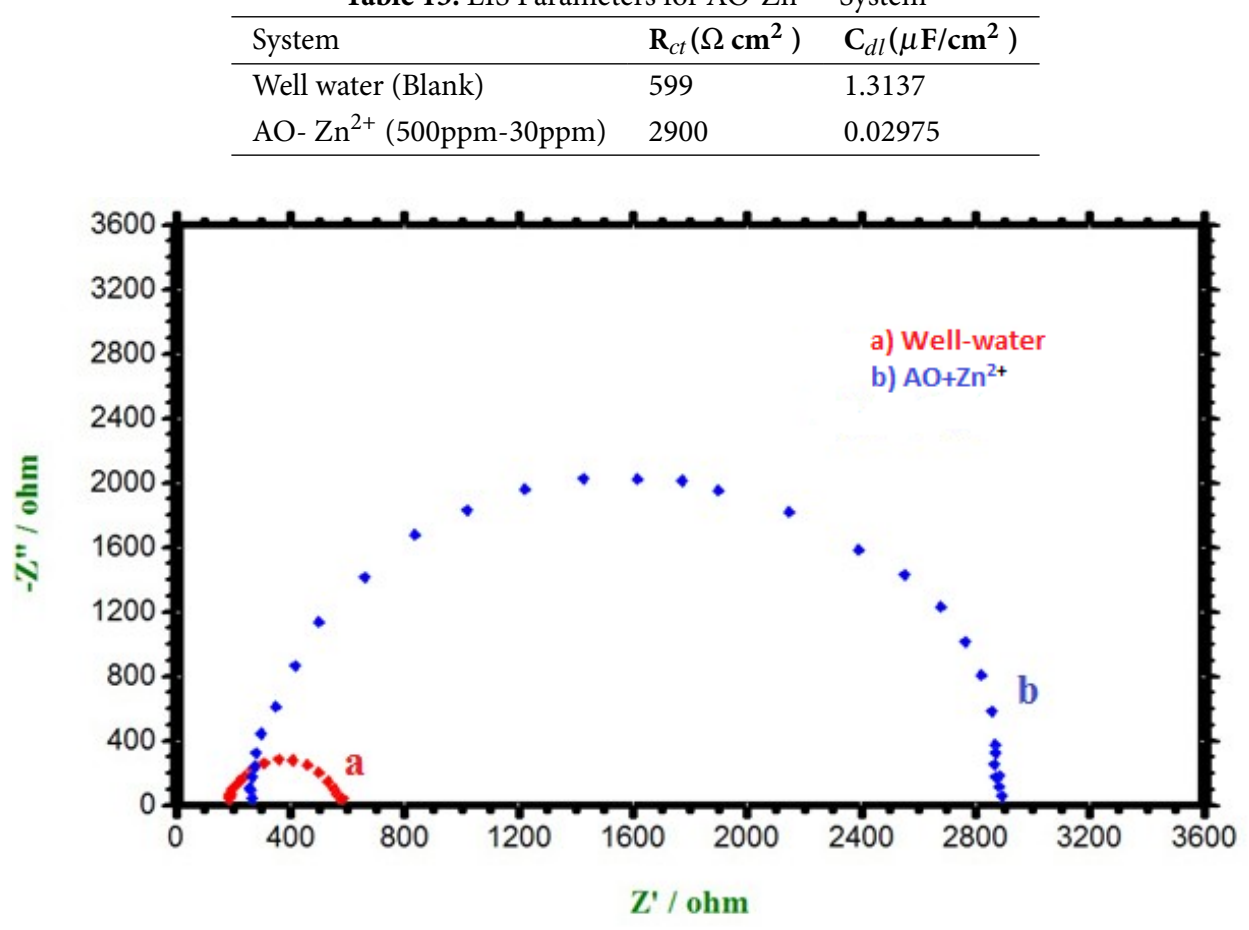

Fig 13. EIS spectra of well-water (a) and $\mathrm{AO}-\mathrm{Zn}^{2+}$ system (b)

\subsection{FT-IR spectra}

Figure 14a displays the FTIR spectra for pure AO extract. A peak at $3441 \mathrm{~cm}^{-1}$ is associated with $-\mathrm{OH}$ bond vibration. The stretching frequency at $1609 \mathrm{~cm}^{-1}$ is assigned for $\mathrm{C}=\mathrm{C}$ bond vibration ${ }^{(84)}$. The peak around $1122 \mathrm{~cm}^{-1}$ indicates $\mathrm{C}-\mathrm{O}$ stretching vibration. The protecting layer produced on the $\mathrm{CS}$ surface in well water for $\mathrm{AO}-\mathrm{Zn}^{2+}$ system is depicted in the figure. A band around $3469 \mathrm{~cm}^{-1}$ and $1617 \mathrm{~cm}^{-1}$ suggests the existence of $-\mathrm{OH}$ and also $\mathrm{C}=\mathrm{C}$ groups sequentially. A band vibration of $\mathrm{C}-\mathrm{O}$ shows around $1121 \mathrm{~cm}^{-1}$. These shifts confirm that the electron cloud density of $\mathrm{C}-\mathrm{O},-\mathrm{OH}$ and $\mathrm{C}=\mathrm{C}$ functional groups in $\mathrm{AO}$. A peak around $620 \mathrm{~cm}^{-1}$ is assigned for the $\mathrm{Zn}$-O groups (Figure $14 \mathrm{~b}$ ).

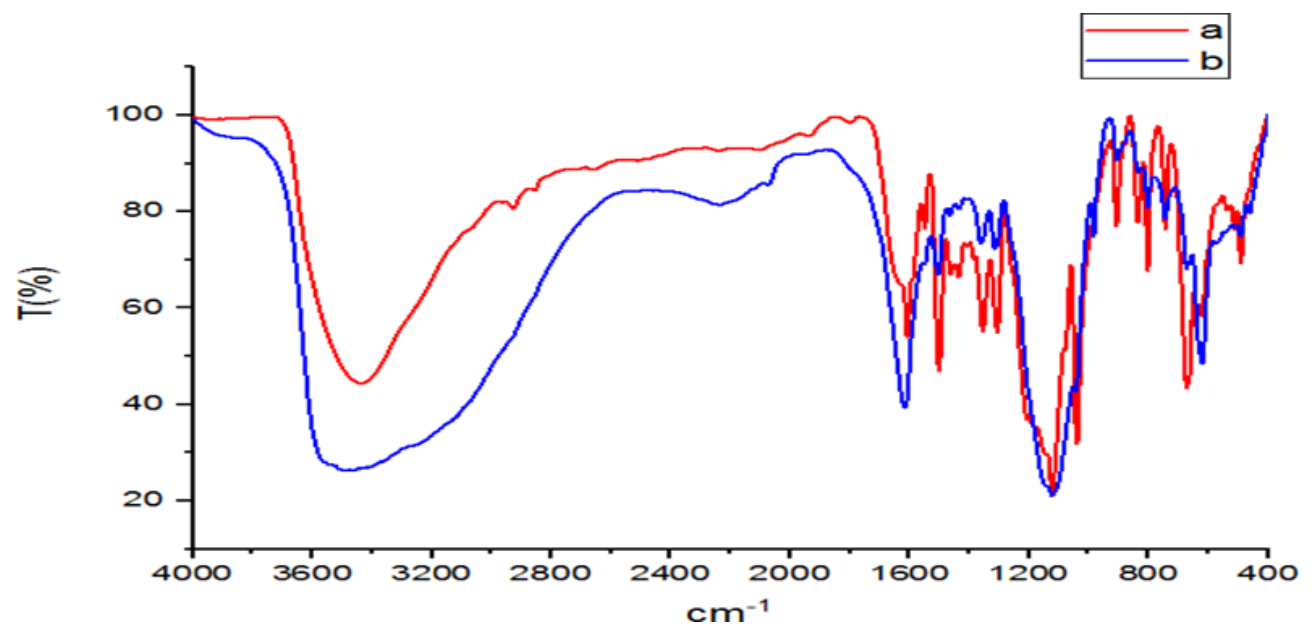

Fig 14. FT-IR spectra for pure $\mathrm{AO}$ extract (a) and $\mathrm{AO}-\mathrm{Zn}^{2+}(500 \mathrm{ppm}-30 \mathrm{ppm})(\mathrm{b})$ 


\subsection{Scanning Electron Microscopy study}

The SEM is an effective tool for examining the surface morphology of $\mathrm{CS}^{(83)}$. The corrosion of uninhibited and inhibited of the CS is investigated by using SEM. As illustrated in Figure 15a, the CS (polished) specimen is smooth and has no corrosion product on the CS site ${ }^{(85)}$. As depicted in Figure 15b, the CS immersed in well water is found to be rough with corrosion product on the CS surface, as well as cracks and damages ${ }^{(86)}$. Because the CS immersed in blank system contains AO (500ppm) and $\mathrm{Zn}^{2+}(30 \mathrm{ppm})$, the surface of the CS becomes smoother and less damaged, as shown in Figure 15c. A highly compact protective film completely covered on the CS surface through adsorption of insoluble the ethanolic extract of AO leaves- $\mathrm{Zn}^{2+}$ composition existing in anodic position and zinc hydroxidedeposits in cathodic position ${ }^{(85)}$.
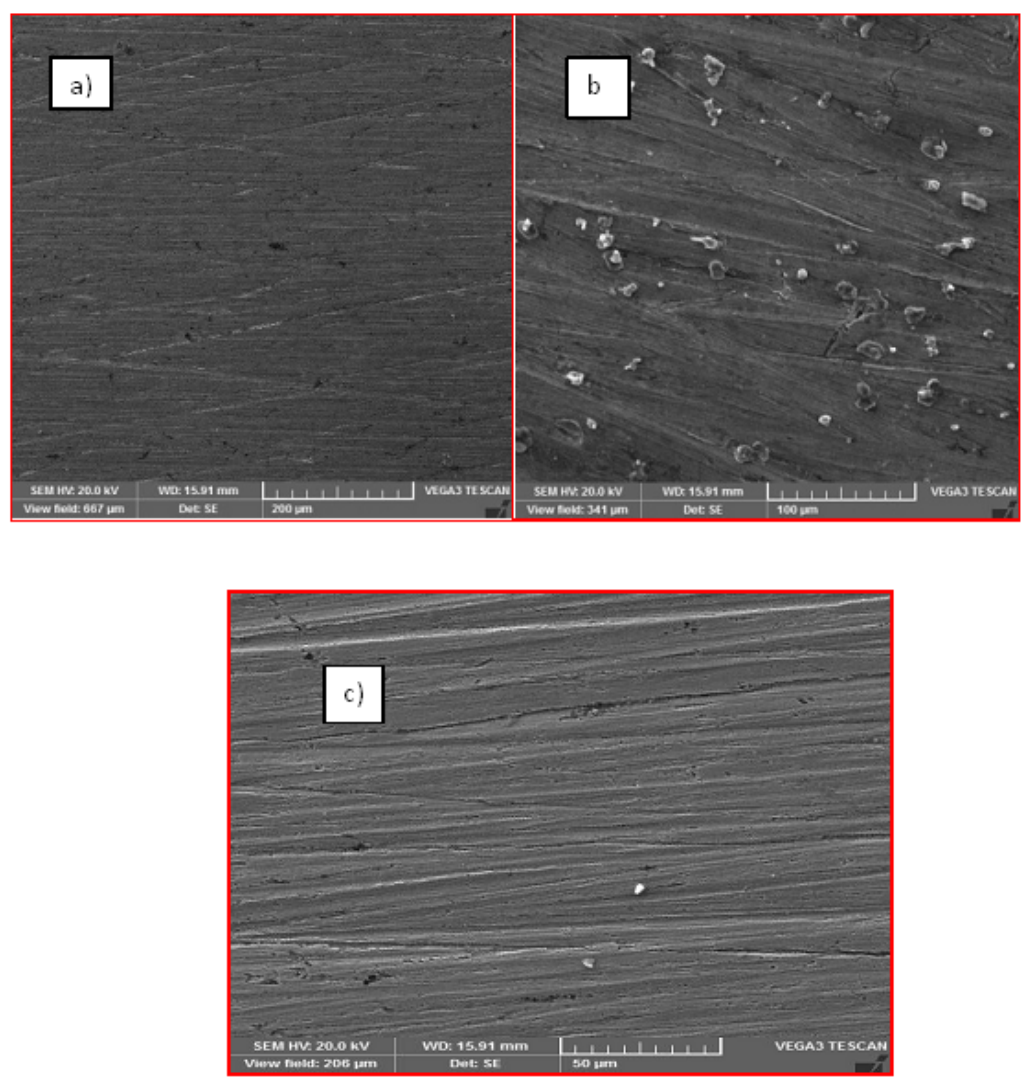

Fig 15. SEM images for polished-CS (a), blank (b) and AO- $\mathrm{Zn}^{2+}$ system (c)

\subsection{AFM analysis}

2D AFM images were analyzed the roughness parameters of pure CS (uncorroded), CS submerged in well water (corroded) and CS submerged in a blank system (well water) with inhibitor systems (protected) are coordinated to visualize the smoother CS surface through the adsorption of inhibitor molecules ${ }^{(55,87,88)}$. Data of AFM parameters are shown in Table 14. Figure 16a shows the CS surface has a smooth texture and lower $\mathrm{R}_{a}, \mathrm{R}_{r m s}$ and $\mathrm{P}-\mathrm{V}$ values. Figure $16 \mathrm{~b}$ shows a severely damaged surface following the corrosive attack without $\mathrm{AO}$ leaves extract, $\mathrm{R}_{a}$ (average roughness), $\mathrm{R}_{r m s}$ (root mean square roughness) and $\mathrm{P}-\mathrm{V}$ (maximum peak-to-valley height) values are increased. Figure 16c, depicts a smoother CS surface that is obviously a smaller amount attacked by the corrosive medium and has $\mathrm{R}_{a}, \mathrm{R}_{r m s}$ roughness part that is greatly closer to the polished CS surface. AFM parameters reveal that a safe film forms onto CS surface from corrosion process ${ }^{(59,89-91)}$, when exposed to the blank solution occurs in the existence of ethanolic extract of AO leaves. 
Table 14. AFM Parameters for $\mathrm{AO}-\mathrm{Zn}^{2+}$ system

\begin{tabular}{llll}
\hline AFM Parameters $(\mathrm{nm})$ & CS-Polished & Well water $($ Blank $)$ & AO-Zn ${ }^{2+}(500 \mathrm{ppm}-30 \mathrm{ppm})$ system \\
\hline $\mathrm{R}_{a}$ & 5.66 & 1317.08 & 16.84 \\
$\mathrm{R}_{r m s}$ & 6.25 & 1476.12 & 20.78 \\
$\mathrm{P}-\mathrm{V}$ & 24.14 & 3791 & 82.36 \\
\hline
\end{tabular}
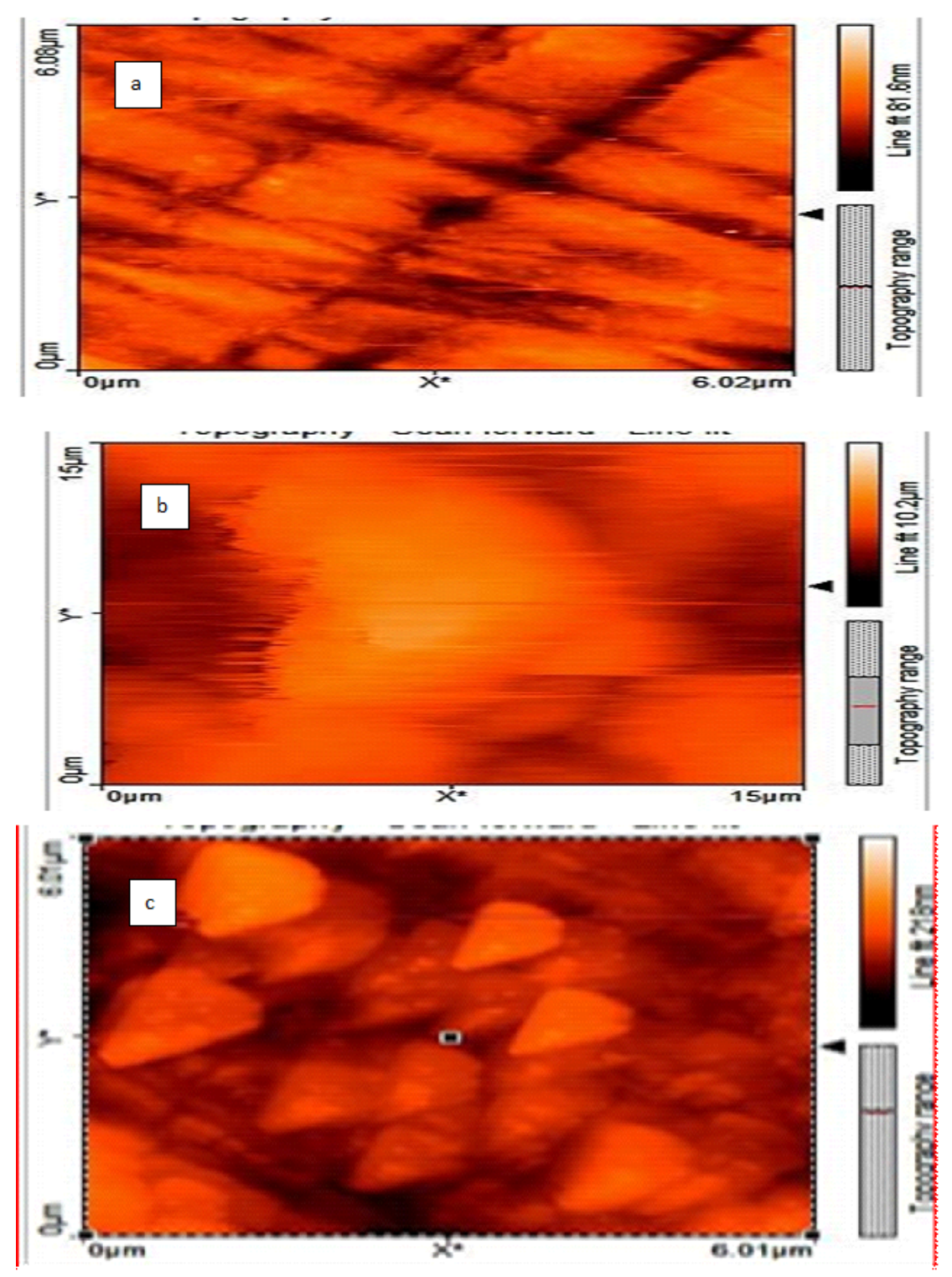

Fig 16. AFM $2 \mathrm{D}$ images for polished-CS (a), blank (b) and AO- $\mathrm{Zn}^{2+}$ system (c) 


\section{Conclusion}

Corrosion kinetic and adsorption thermodynamic effect for AO leaves extract onto CS surface in well-water were investigated using WL measurement. The IE and CR were computed for varied immersion period and temperatures using various concentrations of $\mathrm{AO}$ with $\mathrm{Zn}^{2+}$ ions. The effect of adding $\mathrm{Zn}^{2+}$ as an additive to an ethanolic extract of AO leaves has been explored. The inhibition efficiency (IE) has been found to increase appreciably when $\mathrm{Zn}^{2+}$ ions are added. The AO$\mathrm{Zn}^{2+}(500 \mathrm{ppm}-30 \mathrm{ppm})$ system has a highest IE of $93 \%$. A synergistic effect between the $\mathrm{AO}$ and $\mathrm{Zn}^{2+}$ is proven by the obtained $\mathrm{SI}$ and F-values.Polarization curves reveal that $\mathrm{AO}-\mathrm{Zn}^{2+}$ system behave as a mixed-type inhibitor.Electrochemical impedance spectroscopy directs the CS corrosion is primarily controlled through $\mathrm{R}_{c t}$. The Langmuir model governs the adsorption of ethanolic extract of $\mathrm{AO}$ leaves. Activation energy values for $\mathrm{AO}-\mathrm{Zn}^{2+}$ systems are greater than that of the blank system, implying physisorption. The enthalpy values (positive) imply the reaction on the CS surface is endothermic. The $\Delta \mathrm{G}_{a d s}$ and $\mathrm{q}_{a d s}$ values (negative) reflect that the adsorption of AO leaves extract on the CS surface is a spontaneous activity. The data of $\Delta \mathrm{G}_{a d s}$ ranges from $-16.4 \mathrm{KJ} / \mathrm{mol}$ to $-18.4 \mathrm{KJ} / \mathrm{mol}$, the $\Delta \mathrm{G}_{a d s}$ values are less than $-20 \mathrm{KJ} / \mathrm{mol}$. Hence, the adsorption of ethanolic extract of $A O$ leaves is physisorption. The formation of $\mathrm{Fe}^{2+}$-AO complex with a CS surface is probed using FT-IR data. SEM studies indicate that the barrier layer formed over the CS surface.AFM findings suggest that the smooth surface on the CS is due to the creation of $\mathrm{Fe}^{2+}$-AO complex and also zinc hydroxide coatings on the CS surface.

\section{References}

1) Cookey GA, Vopnu T, Maduelosi JN. Thermodynamic and kinetic studies of the corrosion inhibition of mild steel in $0.5 \mathrm{M} \mathrm{HCl}$ using napoleonae imperialis leaves extract. Journal of chemical Society of Nigeria. 2021;46(3):474-0481. doi:10.2478/auoc-2018-0015.

2) Deyab MA, Osman MM, Elkholy AE, Heakal FET. Green approach towards corrosion inhibition of carbon steel in produced oilfield water using lemongrass extract. RSC Advances. 2017;7(72):45241-45251. Available from: https://dx.doi.org/10.1039/c7ra07979f.

3) Marzorati S, Verotta L, Trasatti S. Green Corrosion Inhibitors from Natural Sources and Biomass Wastes. Molecules. 2018;24(1):48-48. Available from: https://dx.doi.org/10.3390/molecules24010048.

4) Ali E, Badr GE, Fouda A. Citrus sinensis Extract as a Green Inhibitor for the Corrosion of Carbon Steel in Sulphuric Acid Solution. Biointerface Research in Applied Chemistry. 2021;11(6):14007-14020. Available from: https://biointerfaceresearch.com/wp-content/uploads/2021/03/20695837116.1400714020. pdf.

5) Bereket G, Yurt A. The inhibition effect of amino acids and hydroxy carboxylic acids on pitting corrosion of aluminum alloy 7075 . Corrosion Science. 2001;43(6):1179-1195. Available from: https://dx.doi.org/10.1016/s0010-938x(00)00135-9.

6) Rani BEA, Basu BBJ. Green Inhibitors for Corrosion Protection of Metals and Alloys: An Overview. International Journal of Corrosion. 2012;2012:1-15. Available from: https://dx.doi.org/10.1155/2012/380217.

7) Redovnikovic RI, Berkovic K, Kovac S, Furac VJ. Natural honey and black radish juice as tin corrosion inhibitors. Corrosion Science. 2008;50(5):1498-1504. Available from: https://dx.doi.org/10.1016/j.corsci.2008.01.013.

8) Sanyal B. Organic compounds as corrosion inhibitors in different environments - A review. Progress in Organic Coatings. 1981;9(2):165-236. Available from: https://dx.doi.org/10.1016/0033-0655(81)80009-x.

9) Cherrak K, Benhiba F, Sebbar NK, Essassi EM, Taleb M, Zarrouk A, et al. Corrosion inhibition of mild steel by new Benzothiazine derivative in a hydrochloric acid solution: Experimental evaluation and theoretical calculations. Chemical Data Collections. 2019;22:100252-100252. Available from: https://dx.doi.org/10.1016/j.cdc.2019.100252. doi:10.1016/j.cdc.2019.100252.

10) Mahmou C, Bouissoui EM, Bouhlal F, Labjar N, Merimi I, Kaya S, et al. Synergistic effects of aminotris(methylene phosphonic acid) and Zn2+ on the carbon steel corrosion in acid media: An experimental and theoretical approach. International Journal of Corrosion and Scale Inhibition. 2021;10(3):12451281. doi:10.17675/2305-6894-2021-10-3-24.

11) Papavinasam S. Evaluation and Selection of Corrosion Inhibitors. Uhlig's. Corrosion Handbook. 2000;p. 1169-1178. Available from: https://doi.org/10. 1002/9780470872864.ch84.

12) A SF, A HB. Aqueous extract of propolis as corrosion inhibitor for carbon steel in aqueous solutions. African Journal of Pure and Applied Chemistry. 2013;7(10):350-359. Available from: https://dx.doi.org/10.5897/ajpac2013.0524.

13) Ghasemi Z, Tizpar A. The inhibition effect of some amino acids towards Pb-Sb-Se-As alloy corrosion in sulfuric acid solution. Applied Surface Science. 2006;252(10):3667-3672. Available from: https://dx.doi.org/10.1016/j.apsusc.2005.05.043.

14) Ghanyl NAA, El-Shenawy AE, Hussien WAM. The Inhibitive Effect of Some Amino Acids on the Corrosion Behaviour of 316L Stainless Steel in Sulfuric Acid Solution. Modern Applied Science. 2011;5(4):19-29. Available from: https://dx.doi.org/10.5539/mas.v5n4p19.

15) Eddy NO, Ibok UJ, Ita BI. QSAR and quantum chemical studies on the inhibition potentials of some amino acids for the corrosion of mild steel in $\mathrm{H} 2 \mathrm{SO} 4$. Journal of Computational Methods in Sciences and Engineering. 2011;11(1-2):25-43. Available from: https://dx.doi.org/10.3233/jcm-2011-0290.

16) Sivakumar S, Raja AS, Sathiyabama J, Prathipa V. Spectroscopic methods used for analysing protective film formed by L - Histidine on carbon steel. International Journal of Pharmaceutical Drug Analysis. 2014;2(7):601-611. Available from: https://www.researchgate.net/publication/283070646_ Spectroscopic_methods_used_for_analyzing_protective_film_formed_by_L-Histidine_on_carbon_steel.

17) Sahayaraja A, Rajendran S, Nagalakshmi R, Thangakani JA, Pandiarajan M. Eco-Friendly Inhibitor Glycine-Zn2+ System Controlling Corrosion of Carbon Steel in Well Water. European Chemical Bulletin. 2012;2(3):130-136. Available from: https://www.researchgate.net/publication/283078202_ ECO-FRIENDLY_INHIBITOR_GLYCINE-Zn_2_SYSTEM_CONTROLLING_CORROSION_OF_CARBON_STEEL_IN_WELL_WATER.

18) Wu JF, Wang Q, Zhang ST, Yin LL. Methionine as Corrosion Inhibitor of Brass in $\mathrm{O}<$ sub $>2</$ sub $>$-Free $1 \mathrm{M} \mathrm{NaOH}$ Solution. Advanced Materials Research. 2011;308-310(310):241-245. Available from: https://dx.doi.org/10.4028/www.scientific.net/amr.308-310.241.

19) Samy A, Raja AS, Rajendran S. Inhibition of corrosion of carbon steel in well water by arginine -Zn2+ system. Journal of Electrochemical Science and Engineering. 2012;2(2):91-104. 
20) Rajendran SRA, Sathiyabama J, Angel P. Corrosion Control by Amino acetic acid (Glycine)-An Overview. International Journal of Innovative research in Science Engineering and Technology. 2014;3(4):11455-11467. Available from: https://www.researchgate.net/publication/283085106_Corrosion_Control_ by_Aminoacetic_acid_Glycine_an_Overview.

21) Prathipa V, Raja AS. Review on the Assessment of Amino Acids Used As Corrosion Inhibitor of Metals and Alloys. Journal of Chemical Biological Physical Sciences. 2015;5(2):1585-1619. Available from: https://www.researchgate.net/publication/283051663_A_Review_on_the_Assessment_of_ Amino_Acids_Used_As_Corrosion_Inhibitor_of_Metals_and_Alloys.

22) Prathipa V, Raja AS. Synergistic and antagonistic effects of $\mathrm{L}$-alanine as green corrosion inhibitor for carbon steel in aqueous medium. Journal of Advanced Chemical Sciences. 2015;1(2):45-48. Available from: https://www.jacsdirectory.com/journal-of-advanced-chemical-sciences/articleview.php?id=30.

23) Prathipa V, Raja AS, Rajendran S. Electrochemical study and spectroscopic methods used for analyzing protective film formed by L-alanine on carbon steel in well water: A green approach. Journal of Advanced Chemical Sciences. 2015;1(2):59-63. Available from: https://www.jacsdirectory.com/journalof-advanced-chemical-sciences/articleview.php?id=34.

24) Mohan R, Selvaraj SK, Sakthivel A, Amalraj AJ, Sahayaraj JW, Regis A, et al. Corrosion inhibition by Phthalic acid Zn2+ system. International Journal of Engineering Research and Applications. 2014;4(5):22-27. Available from: http://www.ijera.com/papers/Vol4_issue5/Version\%204/D045042227.pdf.

25) Kanimozhi SA, Rajendran S. Aluminum inhibition by potassium permanganate-Zn2+system. Arabian Journal for Science and Engineering. 2009;35(1A):41-52. Available from: https://www.researchgate.net/publication/268001050_ALUMINIUM_INHIBITION_BY_POTASSIUM_ PERMANGANATE-_Zn_2_SYSTEM\#: :text=A\%20synergistic\%20effect\%20exists\%20between,absence\%20and\%20presence\%20of\%20Zn2\%2B. \&text=Polarization\%20study\%20reveals\%20that\%20the,functions\%20as\%20an\%20anodic\%20inhibitor.

26) Rahim A, Kassim J. Recent Development of Vegetal Tannins in Corrosion Protection of Iron and Steel. Recent Patents on Materials Sciencee. 2008;1(3):223231. Available from: https://dx.doi.org/10.2174/1874464810801030223.

27) Aralu CC, Chukwuemeka-Okorie HO, Akpomie KG. Inhibition and adsorption potentials of mild steel corrosion using methanol extract of Gongronema latifoliuim. Applied Water Science. 2021;11(2):1-7. Available from: https://dx.doi.org/10.1007/s13201-020-01351-8.

28) Reza NA, Akhmal NH, Fadil NA, Taib MFM. A Review on Plants and Biomass Wastes as Organic Green Corrosion Inhibitors for Mild Steel in Acidic Environment. Metals. 2021;11(7):1062-1062. Available from: https://dx.doi.org/10.3390/met11071062.

29) Hynes NRJ, Selvaraj RM, Mohamed T, Mukesh AM, Olfa K, Nikolova MP. Aerva lanata flowers extract as green corrosion inhibitor of low-carbon steel in $\mathrm{HCl}$ solution: an in vitro study. Chemical Papers. 2021;75(3):1165-1174. Available from: https://dx.doi.org/10.1007/s11696-020-01361-5.

30) Akinbulumo OA, Odejobi OJ, Odekanle EL. Thermodynamics and adsorption study of the corrosion inhibition of mild steel by Euphorbia heterophylla L. extract in 1.5 M HCl. Results in Materials. 2020;5:100074-100074. Available from: https://dx.doi.org/10.1016/j.rinma.2020.100074.

31) Mazkour A, Hajjaji SE, Labjar N, Lotfi EM, Mahi ME. Investigation of Corrosion Protection of Austenitic Stainless Steel in 5.5M Polluted Phosphoric Acid Using 5-Azidomethyl-7-morpholinomethyl-8-hydroxyquinoline as an Ecofriendly Inhibitor. International Journal of Corrosion. 2021;2021:1-15. Available from: https://dx.doi.org/10.1155/2021/6666811.

32) Fawzy A, Toghan A. Inhibition Evaluation of Chromotrope Dyes for the Corrosion of Mild Steel in an Acidic Environment: Thermodynamic and Kinetic Aspects. ACS Omega. 2021;6(5):4051-4061. Available from: https://dx.doi.org/10.1021/acsomega.0c06121.

33) Umoren SA, Li Y, Wang FH. Electrochemical study of corrosion inhibition and adsorption behaviour for pure iron by polyacrylamide in $\mathrm{H} 2 \mathrm{SO} 4:$ Synergistic effect of iodide ions. Corrosion Science. 2010;52(5):1777-1786. Available from: https://dx.doi.org/10.1016/j.corsci.2010.01.026.

34) Wang B, Du M, Zhang J, Gao CJ. Electrochemical and surface analysis studies on corrosion inhibition of Q235 steel by imidazoline derivative against CO2 corrosion. Corrosion Science. 2011;53(1):353-361. Available from: https://dx.doi.org/10.1016/j.corsci.2010.09.042.

35) Bennett JM, Jahanmir J, Podlesny JC, Balter TL, Hobbs DT. Scanning force microscope as a tool for studying optical surfaces. Applied Optics. 1995;34(1):213-213. Available from: https://dx.doi.org/10.1364/ao.34.000213.

36) Marrese M, Guarino V, Ambrosio L. Atomic Force Microscopy: A Powerful Tool to Address Scaffold Design in Tissue Engineering. Journal of Functional Biomaterials. 2017;8(1):7-7. Available from: https://dx.doi.org/10.3390/jfb8010007.

37) Shivakumar SS, Mohana KN. Centella asiatica extracts as green corrosion inhibitor for mild steel in $0.5 \mathrm{M}$ sulphuric acid medium. Advances in Applied Science Research. 2012;3(5):3097-3106. Available from: https://www.imedpub.com/abstract/centella-asiatica- extracts-as-green-corrosion-inhibitor-formild-steel-inrn05-m-sulphuric-acid-medium-16646.html.

38) Ji G, Shukla SK, Dwivedi P, Sundaram S, Ebenso EE, Prakash R. Green capsicum annuum fruit extract for inhibition of mild steel corrosion in hydrochloric acid solution. International Journal of Electrochemical Science. 2012;7(12):12146-12158. Available from: https://www.researchgate.net/publication/ 262647978_Green_Capsicum_annuum_Fruit_Extract_for_Inhibition_of_Mild_Steel_Corrosion_in_Hydrochloric_acid_solution.

39) Yadav M, Behera D, Sharma U. Development of corrosion inhibitors used in acidization of petroleum oil well. Der chemica sinica. 2012;3(1):262-268. Available from: https://www.researchgate.net/publication/277061107_Development_of_Corrosion_Inhibitors_Used_in_ Acidization_of_Petroleum_Oil_Well.

40) Florez-Frias EA, Barba V, Lopez-Sesenes R, Landeros-Martínez LL, los Ríos JPFD, Casales M, et al. Use of a Metallic Complex Derived from Curcuma Longa as Green Corrosion Inhibitor for Carbon Steel in Sulfuric Acid. International Journal of Corrosion. 2021;2021:1-13. Available from: https: //dx.doi.org/10.1155/2021/6695299.

41) Yang HM. Role of Organic and Eco-Friendly Inhibitors on the Corrosion Mitigation of Steel in Acidic Environments-A State-of-Art Review. Molecules. 2021;26(11):3473-3473. Available from: https://doi.org/10.3390/molecules26113473.

42) Kavitha N, Manjula P, Anandhakumar N. Syneristic effect of C. Papaya Leaves Extract-Zn2+ in Corrosion Inhibition of Mild Steel in Aqueous Medium. Research Journal of Chemical Sciences. 2014;4(8):88-93.

43) Rajendran S, Jeyasundari J, Usha P, Selvi JA, Narayanasamy B, Regis APP, et al. Corrosion Behaviour of Aluminium in the Presence of an Aqueous Extract of Hibiscus Rosa-sinensis. Portugaliae Electrochimica Acta. 2009;27(2):153-164. Available from: https://dx.doi.org/10.4152/pea.200902153. doi:10.4152/pea.200902153.

44) Deyab MA, Guibal E. Enhancement of corrosion resistance of the cooling systems in desalination plants by green inhibitor. Scientific Reports. 2020;10(1):113. Available from: https://dx.doi.org/10.1038/s41598-020-61810-9. doi:10.1038/s41598-020-61810-9.

45) Vennila T, Muneeswaran T, Manjula M, Stalin B, Vairamuthu J. Synergism between sodium molybdate and binary inhibitor (BHI + Zn2+) on corrosion inhibition of mild steel in aqueous medium containing $60 \mathrm{ppm} \mathrm{Cl}-$ ion. Materials Research Express. 2019;6(11):1165g6-1165g6. Available from: https://dx.doi.org/10.1088/2053-1591/ab5233. doi:10.1088/2053-1591/ab5233.

46) Sakthivel M, Kumar C, Selvaraj MR, Micheal SK, Amalraj SM, Sahayaraj AJ, et al. Corrosion Inhibition by an Aqueous Extract of Sansevieria Roxburghiana for Carbon Steel in 60 ppm of Chloride Environment. Chemical Science Review and Letters. 2014;3(11S):188-199. 
47) Epshiba R, Regis A, Clarebel RB, Mary SP, Alphonsa JK. Influence of Aloe vera extract on corrosion inhibition of mild steel in well water. Re TeLL. 2015;15:1-11.

48) Sangeetha M, Rajendran S, Sathiyabama J, Krishnaveni A, Shanthy P, Manimaran N, et al. Corrosion Inhibition by an Aqueous Extract of Phyllanthus Amarus. Portugaliae Electrochimica Acta. 2011;29(6):429-444. Available from: https://dx.doi.org/10.4152/pea.201106429. doi:10.4152/pea.201106429.

49) Al-Senani G, Al-Saeedi S, Almufarij R. Green corrosion inhibitors for carbon steel by green leafy vegetables extracts in $1 \mathrm{M} \mathrm{HCl}$. Oriental Journal of Chemistry. 2015;31(4):2077-2086. Available from: https://dx.doi.org/10.13005/ojc/310428. doi:10.13005/ojc/310428.

50) Fathabadi HE, Ghorbani M, Ghartavol HM. Corrosion Inhibition of Mild Steel with Tolyltriazole. Materials Research. 2021;24(4):1-16. Available from: https://dx.doi.org/10.1590/1980-5373-mr-2020-0395. doi:10.1590/1980-5373-mr-2020-0395.

51) Tomilawo BA, Olasehinde EF, Ani JU, Obagboye FO, Asegbeloyin JN, Obi IO, et al. Corrosion control of mild steel in sulphuric acid by athyrium filixfemina leaf extract green inhibitor. Chemical Science Review and Letters. 2020;9(36):869-885.

52) Al-Senani GM. Corrosion Inhibition of Carbon Steel in acidic chloride medium by Cucumis Sativus (cucumber) Peel Extract. International Journal of Electrochemical Science. 2016;11(1):291-302.

53) Fawzy A, Toghan A. Inhibition Evaluation of Chromotrope Dyes for the Corrosion of Mild Steel in an Acidic Environment: Thermodynamic and Kinetic Aspects. ACS Omega. 2021;6(5):4051-4061. Available from: https://dx.doi.org/10.1021/acsomega.0c06121. doi:10.1021/acsomega.0c06121.

54) Brindha T, Parimalagandhi K, Mallika J. Thermodynamic and Electrochemical Analysis of Synergistic Corrosion Inhibition Performance of Natural Polysaccharides with Metal Halides on Mild Steel in Hydrochloric Acid Solution. Journal of Bio- and Tribo-Corrosion. 2020;6(1):1-10. Available from: https://dx.doi.org/10.1007/s40735-019-0296-7. doi:10.1007/s40735-019-0296-7.

55) Praba KL, Rajam S, Subramania A. The effect of aqueous extract of Adathoda vasica leaves on corrosion inhibition of aluminium in alkaline solution. Journal of chemical and pharmaceutical Research. 2012;4(1):337-347.

56) Gaber A, Rahal HT, Rifai M. Green Approach towards Corrosion Inhibition in Hydrochloric Acid Solutions. Biointerface Research in Applied Chemistry. 2021;11(6):14185-14195.

57) Fouda AEAS, El-Maksoud SAA, El-Sayed EH, Elbaz HA, Abousalem AS. Experimental and surface morphological studies of corrosion inhibition on carbon steel in $\mathrm{HCl}$ solution using some new hydrazide derivatives. RSC Advances. 2021;11(22):13497-13512. Available from: https://dx.doi.org/10.1039/ d1ra01405f. doi:10.1039/d1ra01405f.

58) Prabhu D, Prabhu PR, Rao P. Thermodynamics, adsorption, and response surface methodology investigation of the corrosion inhibition of aluminum by Terminalia chebula Ritz. extract in H3PO4. Chemical Papers. 2021;75(2):653-667. Available from: https://dx.doi.org/10.1007/s11696-020-01318-8. doi:10.1007/s11696-020-01318-8.

59) Tan B, Zhang S, Liu H, Guo Y, Qiang Y, Li W, et al. Corrosion inhibition of X65 steel in sulfuric acid by two food flavorants 2-isobutylthiazole and 1-(1,3Thiazol-2-yl) ethanone as the green environmental corrosion inhibitors: Combination of experimental and theoretical researches. Journal of Colloid and Interface Science. 2019;538:519-529. Available from: https://dx.doi.org/10.1016/j.jcis.2018.12.020. doi:10.1016/j.jcis.2018.12.020.

60) Zhang QB, Hua YX. Corrosion inhibition of mild steel by alkylimidazolium ionic liquids in hydrochloric acid. Electrochimica Acta. 2009;54(6):1881-1887.

61) Begum AAS, Vahith RMA, Kotra V, Shaik MR, Abdelgawad A, Awwad EM, et al. Spilanthes acmella Leaves Extract for Corrosion Inhibition in Acid Medium. Coatings. 2021;11(1):106-106. Available from: https://dx.doi.org/10.3390/coatings11010106. doi:10.3390/coatings11010106.

62) Fakih A, Aziz M, Sirat HM. Turmeric and ginger as green inhibitors of mild steel corrosion in acidic medium. Journal of Materials and Environmental Science. 2015;6(5):1480-1487.

63) Thacker H, Ram V. Phoenix Dactylifera L. Extracts as Green Corrosion Inhibitor for Aluminum in Acidic Medium. Journal of Scientific Research. 2021;65(03):142-149. Available from: https://dx.doi.org/10.37398/jsr.2021.650317. doi:10.37398/jsr.2021.650317.

64) Santhini N, Jeyaraj T. The inhibition effect of [3-(4-hydroxy-3-methoxy-phenyl)-1-phenylpropenone] on the corrosion of the aluminium in alkaline medium. Journal of Chemical and Pharmaceutical Research. 2012;4(7):3550-3556.

65) Ogunleye OO, Arinkoola AO, Eletta OA, Agbede OO, Osho YA, Morakinyo AF, et al. Green corrosion inhibition and adsorption characteristics of Luffa cylindrica leaf extract on mild steel in hydrochloric acid environment. Heliyon. 2020;6(1):e03205-e03205. Available from: https://dx.doi.org/10.1016/j. heliyon.2020.e03205. doi:10.1016/j.heliyon.2020.e03205.

66) Adejo SO, Yiase SG, Ahile UJ, Tyohemba TG, Gbertyo JA. Inhibitory effect and adsorption parameters of extract leaves of Portulaca oleracea of corrosion of aluminium in H2SO4 solution. Archives of Applied Science Research. 2013;5(1):25-32.

67) Oguzie EE. Corrosion inhibition of aluminium in acidic and alkaline media by Sansevieria trifasciata extract. Corrosion Science. 2007;49(3):1527-1539. Available from: https://dx.doi.org/10.1016/j.corsci.2006.08.009. doi:10.1016/j.corsci.2006.08.009.

68) Popova A, Sokolova E, Raicheva S, Christov M. AC and DC study of the temperature effect on mild steel corrosion in acid media in the presence of benzimidazole derivatives. Corrosion Science. 2003;45(1):33-58. Available from: https://dx.doi.org/10.1016/s0010-938x(02)00072-0. doi:10.1016/s0010$938 \mathrm{x}(02) 00072-0$.

69) Thiruppathy J, Ragu M, Ganesanm, Sivasubramanian VK, Karuppasamy P, Rajendran T. Inhibitive action of calcium lignosulfonate on the corrosion of mild steel in sulfuric acid medium. International Journal of Scientific and Research Publications. 2014;4(9):474-481.

70) Parveen M, Mobin M, Zehra S. Evaluation of l-tyrosine mixed with sodium dodecyl sulphate or cetyl pyridinium chloride as a corrosion inhibitor for mild steel in 1 M HCl: experimental and theoretical studies. RSC Advances. 2016;6(66):61235-61248. Available from: https://dx.doi.org/10.1039/c6ra10010d. doi:10.1039/c6ra10010d.

71) Sheeba SR, Raja SA, Sathiyabama J, Prathipa V. Green approach to corrosion inhibition of carbon steel in well water by the extract of Polyalthia longifolia. Journal of applicable chemistry. 2014;3(5):2055-2065.

72) Ferreira ES, Giacomelli C, Giacomelli FC, Spinelli A. Evaluation of the inhibitor effect of l-ascorbic acid on the corrosion of mild steel. Materials Chemistry and Physics. 2004;83(1):129-134. Available from: https://dx.doi.org/10.1016/j.matchemphys.2003.09.020. doi:10.1016/j.matchemphys.2003.09.020.

73) hua Li W, He Q, tao Zhang S, ling Pei C, rong Hou B. Some new triazole derivatives as inhibitors for mild steel corrosion in acidic medium. Journal of Applied Electrochemistry. 2008;38(3):289-295. Available from: https://dx.doi.org/10.1007/s10800-007-9437-7. doi:10.1007/s10800-007-9437-7.

74) Asokan T, Sekar M, Thangavelu C, Sudhakaran R, Kasilingam T. Inhibition and co-adsorption behaviour of Alkylbenzyldimethylammonium chloride on carbon steel in potable water system. Der Chemica Sinica. 2014;5(6):56-63.

75) Sangeetha M, Rajendran S, Sathiyabama J, Prabhakar P. Influence of Murraya koenigii (curry leaves) extract on the corrosion inhibition of carbon steel in HCl solution. Journal of Natural Product and Plant Resources. 2012;2(5):601-610.

76) Bakri EY, Boudalia M, Echihi S, Harmaoui A, Sebhaoui J, Elmsellem H, et al. Performance and theoretical study on corrosion inhibition of new triazolopyrimidine derivative for carbon steel in hydrochloric acid. Journal of Materials and Environmental Sciences. 2017;8(2):378-388. 
77) Sribharathy V, Rajendran S, Rengan P, Nagalakshmi R. Corrosion Inhibition by an Aqueous Extract Of Aloe Vera (L.) Burm F.(Liliaceae). European Chemical Bulletin. 2013;2(7):471-476.

78) Sharmila A, Prema AA, Sahayaraj PA. Influence of Murraya koenigii (curry leaves) extract on the corrosion inhibition of carbon steel in HCL solution. Rasayan Journal of Chemistry. 2010;3(1):74-81.

79) Leçe HD, Emregül KC, Atakol O. Difference in the inhibitive effect of some Schiff base compounds containing oxygen, nitrogen and sulfur donors. Corrosion Science. 2008;50(5):1460-1468. Available from: https://dx.doi.org/10.1016/j.corsci.2008.01.014. doi:10.1016/j.corsci.2008.01.014.

80) Antony N, Sherine HB, Rajendran S. Inhibition and Biocide Actions of Sodium Dodecyl Sulfate-Zn2+ System for the Corrosion of Carbon Steel in Chloride Solution. Portugaliae Electrochimica Acta. 2010;28(1):1-14. Available from: https://dx.doi.org/10.4152/pea.201001001. doi:10.4152/pea.201001001.

81) Touir R, Dkhireche N, Touhami ME, Sfaira M, Senhaji O, Robin JJ, et al. Study of phosphonate addition and hydrodynamic conditions on ordinary steel corrosion inhibition in simulated cooling water. Materials Chemistry and Physics. 2010;122(1):1-9. Available from: https://dx.doi.org/10.1016/j. matchemphys.2010.02.063. doi:10.1016/j.matchemphys.2010.02.063.

82) Li X, Deng S, Fu H. Triazolyl blue tetrazolium bromide as a novel corrosion inhibitor for steel in $\mathrm{HCl}$ and $\mathrm{H} 2 \mathrm{SO} 4$ solutions. Corrosion Science. 2011;53(1):302-309. Available from: https://dx.doi.org/10.1016/j.corsci.2010.09.036. doi:10.1016/j.corsci.2010.09.036.

83) Sherine HB, Rajendran S. Corrosion Inhibition of Carbon Steel in Ground Water by Thiophenol-Zn2+ System. Arabian Journal for Science and Engineering. 2011;36(4):517-528. Available from: https://dx.doi.org/10.1007/s13369-011-0067-3. doi:10.1007/s13369-011-0067-3.

84) Delimi A, Galopin E, Coffinier Y, Pisarek M, Boukherroub R, Talhi B, et al. Investigation of the corrosion behavior of carbon steel coated with fluoropolymer thin films. Surface and Coatings Technology. 2011;205(16):4011-4017. Available from: https://dx.doi.org/10.1016/j.surfcoat.2011.02.030. doi:10.1016/j.surfcoat.2011.02.030.

85) Wang X, Yang H, Wang F. A cationic gemini-surfactant as effective inhibitor for mild steel in HCl solutions. Corrosion Science. 2010;52(4):1268-1276. Available from: https://dx.doi.org/10.1016/j.corsci.2009.12.018. doi:10.1016/j.corsci.2009.12.018.

86) Onyeachu IB, Njoku DI, Kaya S, Ibrahimi B, Nnadozie CF. Sour corrosion of C1018 carbon steel and its inhibition by computational assessment. Journal of Adhesion Science and Technilogy. 2021;p. 1-21.

87) de Sampaio MTG, Fernandes CM, de Souza GGP, Carvalho ES, Velasco JAC, Silva JCM, et al. Evaluation of Aqueous Extract of Mandevilla fragrans Leaves as Environmental-Friendly Corrosion Inhibitor for Mild Steel in Acid Medium. Journal of Bio- and Tribo-Corrosion. 2021;7(1):1-11. Available from: https://dx.doi.org/10.1007/s40735-020-00445-9. doi:10.1007/s40735-020-00445-9.

88) Fathima H, Pais M, Rao P. The Use of Green Inhibitors in Evaluating the Safe Expiry Dates of Therapeutics. Journal of Bio-and Tribo-Corrosion. 2021;7(3):19. Available from: https://dx.doi.org/10.1007/s40735-021-00544-1. doi:10.1007/s40735-021-00544-1.

89) Bidi MA, Azadi M, Rassouli M. A new green inhibitor for lowering the corrosion rate of carbon steel in $1 \mathrm{M} \mathrm{HCl}$ solution: Hyalomma tick extract. Materials Today Communications. 2020;24:100996-100996. Available from: https://dx.doi.org/10.1016/j.mtcomm.2020.100996. doi:10.1016/j.mtcomm.2020.100996.

90) Prabakaran M, Kim SH, Hemapriya V, Chung IM. Evaluation of polyphenol composition and anti-corrosion properties of Cryptostegia grandiflora plant extract on mild steel in acidic medium. Journal of Industrial and Engineering Chemistry. 2016;37:47-56. Available from: https://dx.doi.org/10.1016/j.jiec. 2016.03.006. doi:10.1016/j.jiec.2016.03.006.

91) Umoren SA, Solomon MM, Ali SA, Dafalla HDM. Synthesis, characterization, and utilization of a diallylmethylamine-based cyclopolymer for corrosion mitigation in simulated acidizing environment. Materials Science and Engineering: C. 2019;100:897-914. Available from: https://dx.doi.org/10.1016/j. msec.2019.03.057. doi:10.1016/j.msec.2019.03.057. 